\title{
Cystic fibrosis lung environment and Pseudomonas aeruginosa infection
}

\author{
Anjali Y. Bhagirath ${ }^{1,3}$, Yanqi Li $i^{1,3}$, Deepti Somayajula ${ }^{1,3}$, Maryam Dadashi ${ }^{1,3}$, Sara Badr ${ }^{2,3}$ and Kangmin Duan ${ }^{1,2,3^{*}}$
}

\begin{abstract}
Background: The airways of patients with cystic fibrosis (CF) are highly complex, subject to various environmental conditions as well as a distinct microbiota. Pseudomonas aeruginosa is recognized as one of the most important pulmonary pathogens and the predominant cause of morbidity and mortality in CF. A multifarious interplay between the host, pathogens, microbiota, and the environment shapes the course of the disease. There have been several excellent reviews detailing CF pathology, Pseudomonas and the role of environment in CF but only a few reviews connect these entities with regards to influence on the overall course of the disease. A holistic understanding of contributing factors is pertinent to inform new research and therapeutics.

Discussion: In this article, we discuss the deterministic alterations in lung physiology as a result of CF. We also revisit the impact of those changes on the microbiota, with special emphasis on P. aeruginosa and the influence of other non-genetic factors on CF. Substantial past and current research on various genetic and non-genetic aspects of cystic fibrosis has been reviewed to assess the effect of different factors on CF pulmonary infection. A thorough review of contributing factors in CF and the alterations in lung physiology indicate that CF lung infection is multifactorial with no isolated cause that should be solely targeted to control disease progression. A combinatorial approach may be required to ensure better disease outcomes.

Conclusion: CF lung infection is a complex disease and requires a broad multidisciplinary approach to improve CF disease outcomes. A holistic understanding of the underlying mechanisms and non-genetic contributing factors in CF is central to development of new and targeted therapeutic strategies.
\end{abstract}

Keywords: Cystic fibrosis, Host-pathogen interaction, Microbiome, CFTR, Non-genetic influences

\section{Background}

Cystic fibrosis (CF) is the most common life-threatening autosomal recessive genetic disease in Caucasians. The estimated incidence of CF is one in 2500-4000 within the Caucasian population and holds a prevalence of about 100,000 globally [1]. Fortunately, the incidence rate and overall prevalence for $\mathrm{CF}$ has been declining [2] over the recent years. This is a result of neonatal screening and newer treatment modalities such as improved control of pulmonary infections and mucociliary clearance. However, recent years have also seen an increase in disease complexity [3] with newer, more resistant

\footnotetext{
* Correspondence: Kangmin.Duan@umanitoba.ca

'Department of Oral Biology, Rady Faculty of Health Sciences, University of

Manitoba, 780 Bannatyne Ave, Winnipeg, MB R3E OW2, Canada

${ }^{2}$ Department of Medical Microbiology, Rady Faculty of Health Sciences,

University of Manitoba, 780 Bannatyne Ave, Winnipeg, MB R3E OW2, Canada

Full list of author information is available at the end of the article
}

genetic variants [4] often emerging. Some of these have been covered very well in several excellent reviews [3, 5-7]. One common theme that gets less than deserved attention is the interplay of immediate environmental factors in shaping the course of disease progression. We believe that a thorough understanding of the environmental factors can help in defining the course of the disease. With such knowledge, a more appropriate and patient-specific treatment approach can be taken. Though there are several excellent reviews that cover aspects of CF and CF lung environment, this article aims to provide a comprehensive review on recent knowledge on the influence of the lung environment in shaping the disease in a holistic manner. 


\section{Discussion}

\section{The pathophysiology of cystic fibrosis}

CF is caused by mutations in the cystic fibrosis transmembrane conductance regulator [CFTR] gene. Currently, more than 2000 mutations have been identified, of which 127 are confirmed as diseasecausing [8]. However, the molecular mechanisms underlying the strict transcriptional regulation of CFTRs remain poorly understood. CFTR/ABCC7 is a cyclic adenosine monophosphate (cAMP)-dependent member of the adenosine triphosphate (ATP)-binding cassette transporter super family, found in the apical membrane of epithelial cells. It is the only member of the ATP-binding cassette protein family known to function as an ion channel rather than as an active transporter. CFTRs are expressed in many organs such as the kidneys, pancreas, intestine, heart, vas deferens and lungs [9]. CFTRs have been shown to perform a significant role in regulation of sodium [10-12], potassium [13-15], outward rectifying chloride channels [16, 17], calcium-activated chloride channels $[18,19]$, sodium bicarbonate $[20,21]$ and aquaporin [22] channels. Other CFTR functions include the regulation of vesicle trafficking, ATP release, and the expression of inflammatory epithelial mediators (Interleukin 8 and 10, and inducible nitric oxide synthase) [23]. These findings link the complex and diverse CFTR functions to CF lung disease.

Structurally, a CFTR is a membrane-bound glycoprotein of 1480 amino acid residues, with a molecular mass of 170,000. CFTR has a typical architecture of 12 transmembrane spanning helices arranged into two pseudo-symmetrical transmembrane domains and two nuclear-binding domains (NBDs) which bind and hydrolyze ATP and contain several highly conserved motifs (Fig. 1a) [24-28]. These two NBDs, NBD1 and NBD2, can form a "head-to-tail" dimer, forming two composite binding sites for ATP at their interface. Between the two NBD units is a unique regulatory $(\mathrm{R})$ domain which is made up of many charged amino acids [29]. The loss of phenylalanine at position 508 in the CFTR gene is the most common mutation in CF and occurs in a highly conserved $\alpha$-helical sub domain (495-565) in NBD1 (Fig. 1b) [30]. Similarly, many of the other identified mutations have also been observed to occur in NBD1, while relatively few occur in NBD2.

In a non-mutated CFTR, gating has been shown to be tightly coupled with ATPase cycles through NBD Dimerization, which then induces the formation of a transmembrane domain cavity that opens towards the extracellular side to allow for selective anion flow (Fig. 1c) [31-33]. Deletion of phenylalanine at 508

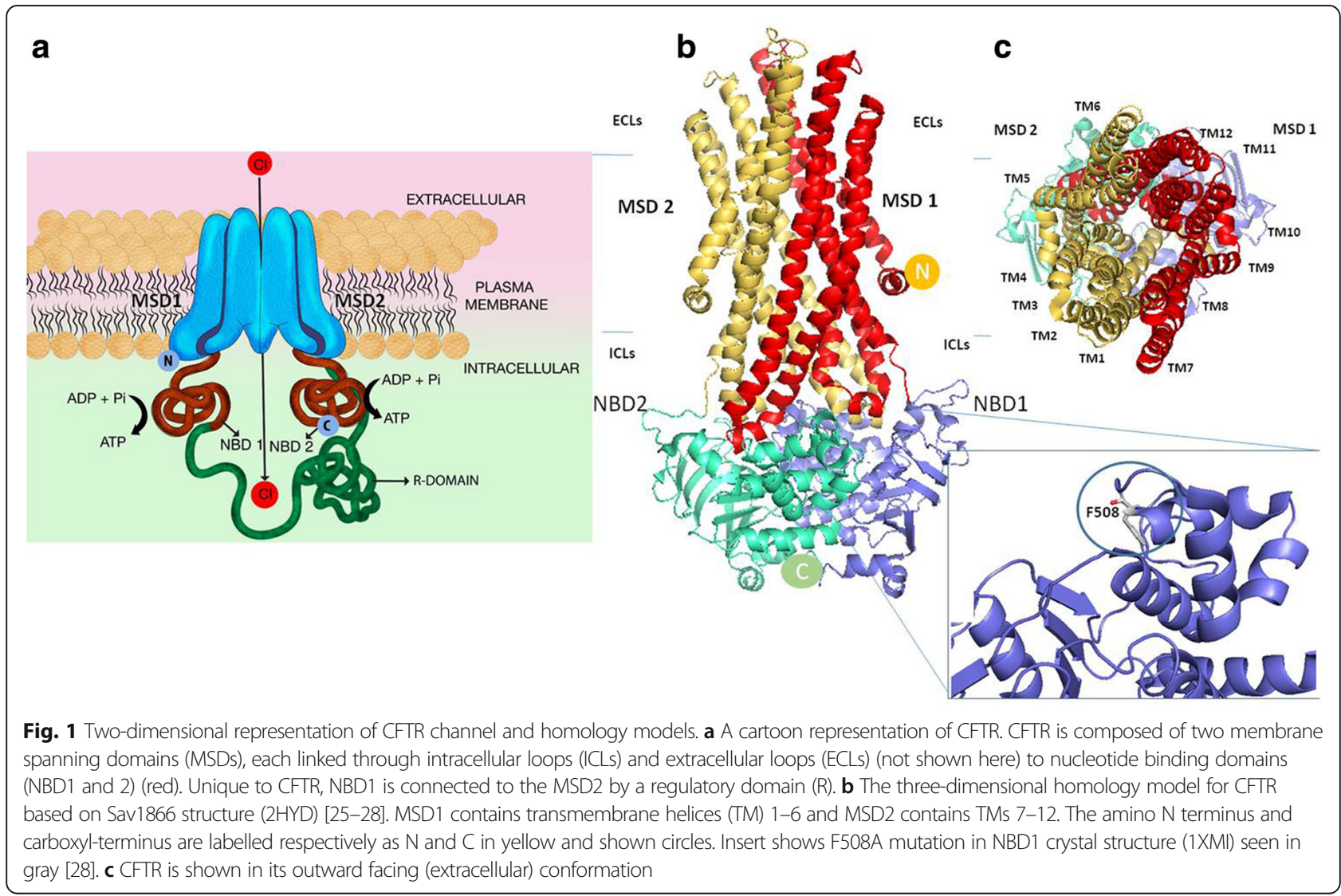


(F508del) in NBD1 leads to a CFTR trafficking defect. Biophysical studies of F508del in solution with "stabilizing mutations" at a second site (s) demonstrated inherent alterations in kinetic and thermal stability [34-36]. Studies also observed that Mg-ATP binding delays unfolding of the wild-type but not the mutated NBD1 [36]. Fluorescence resonance energy transfer studies however showed that F508del mutation does not impair ATP binding, rather it affects ATP-dependent interactions between the two non-contiguous regions in the core F1-ATPase domain of NBD1 [37]. It has also been shown that the intra-domain defect caused by F508del in NBD1 affects the assembly of the full-length CFTR protein and eventually the post-translational stability. This instability affects the maturation of core glycosylated F508del-CFTR to a complex glycosylated protein and leads to endoplasmic retention [37] and eventually decreased expression of the functional protein on the cell surface [29]. Thus, it was hypothesized that the defect may be corrected by improving the interaction between NBD1 and NBD2. However, interventions aimed at disrupting or enhancing the interaction of NBD1 and NBD2 have not been shown to affect the biosynthesis and processing of F508del-CFTR.

NBD-intracellular loop (ICL) interactions have been shown to be involved in ATP binding and channel gating. Studies have observed an interaction between NBD's interface and ICL2 and ICL4 in the wild type; this interaction is altered in F508del with effect on channel gating. Interventions designed to modify the interaction between the surface on NBD1 lacking F508 and the coupling helix presented by ICL4 have been shown to significantly enhance the biosynthesis and processing of F508del-CFTR [38, 39]. Mendoza et al. [38] also described mutations in the coupling helix of ICL4 that cause ER retention (L1065P, R1066C, and G1069R), supporting the idea that this region does play a role in mediating significant interactions during folding. For details of CFTR protein function, readers are referred to articles by Borowitz, Eborn, and Meyerholz [20, 40, 41].

The current paradigm is not to view CFTR as just an ion channel, but a signaling system. It has been hypothesized that if the cellular environment can be altered, the CFTR protein defect may be bypassed. One of the ways to approach this is by improving proteostasis in CF cells [42-44]. Proteostasis improvement helps to re-establish the plasma membrane localization of CFTR. This is achieved by remodeling the F508del-CFTR interactome and avoiding unwanted interactions, thus reinstating desirable protein-protein interactions for F508del-CFTR [43]. In pigs and mice with CFTR defect, administration of proteostasis modulators such as cysteamine significantly reduced mortality, improved weight gain, and increased the expression of functional CFTR protein at the intestinal level [43].

Owing to the complex function of CFTR, multiple physiological disorders arise in CF. Dysfunctional CFTR in the secretory epithelial cells results in obstructions in the lung airways and pancreatic ducts as a major pathological consequence. In CF airways, CFTR dysfunction or absence instigates the accumulation of abnormally thick, sticky mucus in the respiratory tract, which hampers bacterial mucociliary clearance and allows the colonization of the airways by microbial pathogens (discussed further in the following sections). The most notable bacterial pathogens include Pseudomonas aeruginosa, Staphylococcus aureus, Haemophilus influenzae and Burkholderia cepacia complex, with P. aeruginosa causing the most predominant lung infection in $\mathrm{CF}$. The dominant chronic inflammation is generated by the failure of microbial clearance and the creation of a toxic pro-inflammatory local microenvironment, which damages the lung and the innate immunity, further facilitating infections.

Normally, airway epithelial cells can ingest the invading pathogens such as $P$. aeruginosa, followed by desquamation, thus protecting lungs from injury. In $\mathrm{CF}$, however it has been observed that CF epithelial cells phagocytose fewer cells of $P$. aeruginosa [45]. It was initially suggested that CFTR is a cell-surface receptor for $P$. aeruginosa with an intact lipopolysaccharide [LPS] core [45]. However, it was later understood that the internalization of $P$. aeruginosa in epithelial cells does not involve the chloride conductance channels but lipid rafts [46]. After P. aeruginosa enters cultured epithelial cells, the infected cells display plasma membrane blebs, while others show co-localization to acidic vacuoles [46]. An increased apoptosis has also been observed in such blebbing cells [45]. It has been suggested that the blebbing may be a response to $P$. aeruginosa LPS. Prolonged and repeated Pseudomonas LPS exposure in CF mice has been shown to result in abnormal and persistent immune response and significant structural changes in the lungs [46]. Murine CF macrophages with reduced autophagosome formation cause hypersecretion of IL$1 \beta$ and enhanced survival of Burkholderia cenocepacia [43, 47-49], another co-habiting pathogen in CF lungs. Airway acidification by the abnormal CFTR function has also been shown to be a major factor that initiates host defense abnormalities and microbial colonization [50]. Although the detailed mechanisms of the high susceptibility of the CF lung to bacterial infections are not completely clear, increasing data are gradually revealing the properties of abnormal CFTR associated with the prevalent infection with $P$. aeruginosa and other pathogens.

What becomes clear, however, is that CF lung pathogenesis begins with the altered lung environment 
triggered by the abnormal CFTR. A major outcome of changes in lung environment is a shift of the balance between surviving microorganisms that enter the lung and the host defense mechanisms, which eventually result in conditions that favors the survival of the invading microbes together with a persistent yet ineffective immune responses.

\section{The host: Internal environment in cystic fibrosis}

The lung environment in CF is different from that of healthy people and undergoes significant alterations over the course of a patient's lifetime in terms of disease progression, microbial infections and the lung microbiota. The lung environment dictates host-microbe interactions which shape the course of disease. In the healthy respiratory system, the upper respiratory tract is colonized by microorganisms comprising the normal flora while the lower respiratory tract is relatively sterile due to the various host innate defenses. The presence of a microbiota and colonization of respiratory pathogens in lower respiratory tract of CF patients suggests fundamental differences between the CF airways and those of the healthy individuals. Such differences not only provide survivable conditions for the microbes but also alter the host-pathogen interaction. It is thus important to understand the internal environment in the CF lung.

\section{Airway anatomical complexity as a contributor to disease}

The human airway is highly compartmentalized, with the upper respiratory tract, consisting of the nose and the paranasal sinuses followed by the lower respiratory tract, which is further divided into conductive and respiratory zones (Fig. 2a and b). The sinuses in the upper respiratory tract have comparatively less airflow and are more separated from antibiotic exposure and host immune responses. Their primary function is to provide resonance to sounds and produce mucus to facilitate bacterial clearance. The shape and size of the airways impacts the overall flow and resistance of air passing through them. Airway morphology is essential to lung function and has been suggested to be an indicator for disease severity in patients with respiratory disease including CF [51]. Understanding airway complexity is critical to understanding respiratory symptoms, developing ways to facilitate efficient delivery of inhaled medications, and improve mucus clearance.

Studies from animal models suggest that CF patients present with abnormalities in the size and shape of the trachea from birth [52]. Pulmonary imaging of young children with CF indicates early structural defects, even in those with normal pulmonary function test results [52]. It has been observed that the airways of infants and young children with CF have thicker walls, with higher dilation, than those of normal infants [52, 53]. The sinuses in CF form a very well-protected habitat given the complexity of the anatomy and the viscidity of mucus lining it. These make them an excellent reservoir for chronic and relapsing lower respiratory infections. It has been reported that CF patients often present with chronic rhinosinusitis [54] and sinus microbiota in $\mathrm{CF}$ is often considered to be predictive of pulmonary disease [54-57].

In the lower respiratory tract, the conductive zones produce mucus and facilitate bacterial clearance, leaving the alveoli generally free of bacteria. Mucus within the conductive zones is produced by submucosal glands which occur at a frequency of about 1 per $\mathrm{mm}^{2}$ in trachea and go down to airway lumen diameters of 1-2 mm (Fig. 3a). In healthy humans, sub-mucosal glands provide more than $95 \%$ of upper

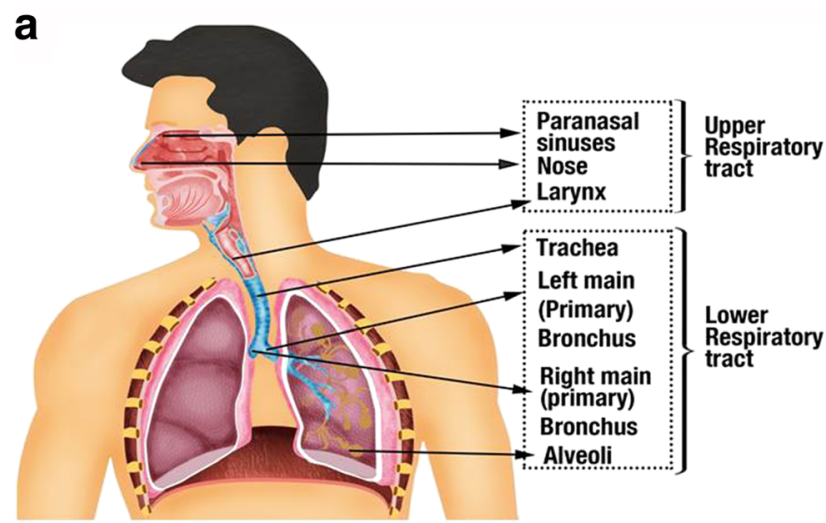

b

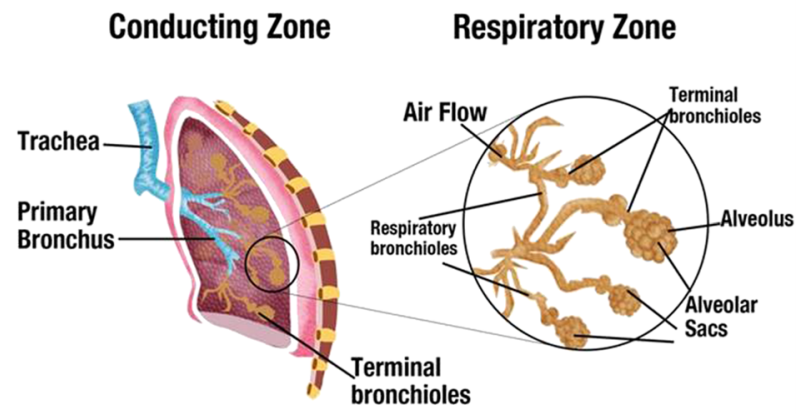

Fig. 2 The different anatomical divisions of human respiratory system relevant to CF lung disease. Environmental factors such as oxygen and nutrient availability vary significantly in different regions of the human respiratory system and influence disease outcomes. a The airway can be divided primarily into the upper and lower respiratory tract. $\mathbf{b}$ Lower respiratory tract is further divided into conductive zone and the respiratory zone. The conducting zones consist of trachea, primary and terminal bronchioles. The conducting zones are secretory in function. The respiratory zones perform the function of air exchange and consist of respiratory bronchioles and alveolar sacs 


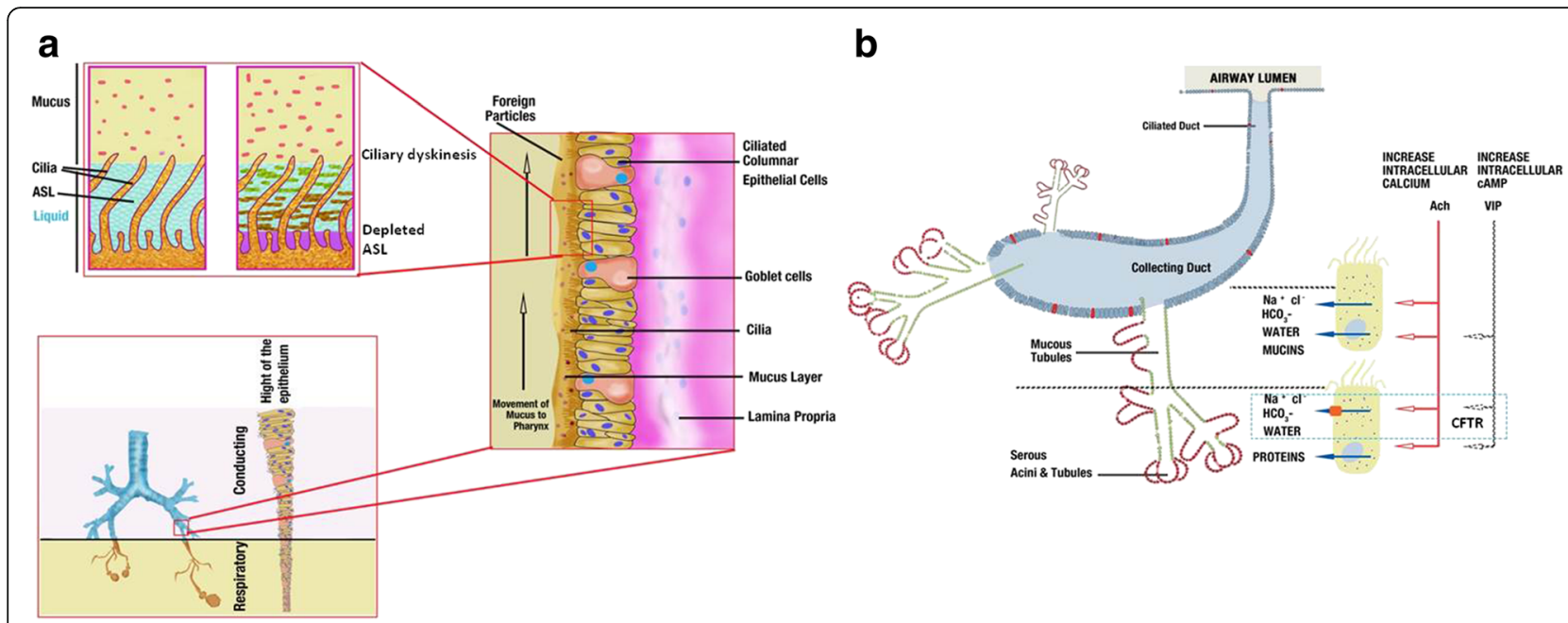

Fig. 3 Anatomical distribution of mucus secreting cells in normal airways and pathological alterations in CF. a Mucus is secreted by submucosal glands in the conductive zone and paranasal sinuses. The submucosal glands go on decreasing towards the lowest components of the respiratory zone. In healthy individuals, the cilia of the epithelial cells clear irritants and microorganisms, trapping them in the thin fluidic mucus and clearing by rhythmic ciliary beating upwards known as mucous escalator. In CF, the airway surface liquid layer thins and the mucus comes in contact with cilia resulting in ciliary dyskinesis, causing poor clearance of bacteria which exacerbates inflammation. $\mathbf{b}$ Schematic drawing of a single submucosal gland shows serous acini, mucus tubules, and collecting duct. Secretion of water across the epithelium of airway glands is driven predominantly by active secretion of chloride and bicarbonate. The CFTR-dependent water-secreting pathway is defective in CF. Figure adapted from previous publications $[54,55,57,59]$

airway mucus. Each gland is composed of tubules that feed into a single collecting duct, which then narrows into a ciliated duct that is continuous with the airway surface. Tubules are lined with mucous cells in their proximal regions and serous cells in the distal acini $[54,58,59]$. Normal glands are made up of $60 \%$ serous and $40 \%$ mucous cells by volume. The serous cells secrete water, electrolytes, and a mixture of compounds with antimicrobial, anti-inflammatory and antioxidant properties, while mucous cells provide most of the mucins. Of relevance to CF is the observation that within airways, CFTRs are most highly expressed in serous cells [55-57] (Fig. 3b). Secretion of water across these glands is driven predominantly by active secretion of chloride and bicarbonate as well as increase in intracellular cAMP. Both cAMP and $\mathrm{Cl}$ ${ }^{-} / \mathrm{HCO}_{3}^{-}$can be stimulated by a variety of agonists that elevate either cAMP, $\mathrm{Ca}^{2+}$, or both, such as cholinergic agents and vasoactive intestinal peptide [54, 60-62]. In tracheobronchial airways of animal models, it was observed that the inhibition of $\mathrm{Cl}^{-}$and $\mathrm{HCO}_{3}^{-}$secretion by bumetanide and dimethylamiloride in submucosal glands produces CF-like pathology, including production of thick dehydrated mucus and occlusion of gland ducts [63, 64]. The mucus secretions from the submucosal glands in lower airways are also important for mucociliary clearance and provide major antimicrobial proteins involved in airway defense against bacteria. The abnormalities in CF lung secretions will be discussed in the next section.

The CF respiratory tract is a highly diverse and complex ecosystem posing several challenges to inhabiting microorganisms in the process. These challenges include oxygen and nutrient limitation, antibiotics, competing microorganisms, changing lung pathophysiology and hyperactive immune response. In healthy individuals, while the upper airways present the anatomical component that may favor bacterial colonization, the lower airways present a more complex interplay of anatomical variations with other factors such as oxygen availability and exaggerated immune response to invading microbes. The CFTR defect in CF changes the airway environment and anatomical parameters in the lower airways. The CF lower airways host diverse microorganisms and pathogens that are usually absent in healthy individuals. In addition, the microorganisms including pathogens evolve in these conditions to give rise to persisters [65-67] and mutators [68-72] that are capable of long-term surviving and colonizing the otherwise harsh lung environment [73]. It is plausible that the complex anatomical and physiological environments make CF lung a distinctive ecosystem with various niches that are eventually occupied by fitting microorganisms. This is supported by the different microbiota observed in different parts of the airways [74], and intrapulmonary spread of pathogens to previously unaffected niches [75]. The presence of active subpopulations of bacteria in particular areas of the airways is suggested to be potentially involved in pulmonary exacerbations in CF [76].

\section{Cystic fibrosis sputum}

The mucociliary system consists of the cilia, the mucus layer covering the airway and the airway surface liquid 
(ASL) layer. This mucus layer is separated from the underlying ciliated epithelium by the liquid phase ASL. The mucus forms a trap for bacteria, viruses, as well as other particles and molecules inhaled during respiration, and the ciliary beating carries them back to the pharynx by forming a "mucus escalator" where they are normally swallowed. Mucus production is thus an innate defense mechanism, which protects airway surfaces against irritants and infecting microorganisms. Mucus composition and viscoelastic properties are good indicators of pulmonary health [77]. Lamblin correctly reviews mucus as "an interface between the environment and the milieu interieur".

In normal airways, if the ASL thins beyond a critical point, the surface epithelium converts from absorptive to secretory, though the exact mechanism is unclear. In CF, the defect in CFTR function leads to further absorption of isotonic liquid from ASL, leading to increase in thinning and viscosity of ASL. Thus, the gel-forming mucins that would otherwise float above the cilia are brought into close contact with the airway surface and attach to it. The antimicrobials within these mucus plaques soon become ineffective and invading microbes proliferate. The viscous mucous impairs ciliary beating, resulting in pulmonary ciliary dyskinesis, which results in the formation of mucous plaques. These mucus plaques, along with infecting microorganisms and resulting airway inflammation, lead to a decline in lung function. Conditions within the plaques, such as low $\mathrm{O}_{2}$ tension, have been shown to contribute further to the airway colonization by pathogens such as $P$. aeruginosa and Streptococcus spp. [78, 79].

Normal mucus is about $95-98 \%$ water and $2-5 \%$ of mucins with other materials. Mucins form a part of the airway innate immunity and play a very critical role in CF disease progression and treatment outcomes but also remain one of the poorly understood aspects of CF. In $\mathrm{CF}$, the mucin to water ratio is about $5-10$ fold higher than normal, with mucus viscoelasticity $10^{4}-10^{5}$ fold greater than water at shear rates comparable to rubber [80]. Human airway mucins comprise a very broad family of high molecular weight glycoproteins. Structurally, mucins contain anywhere from one to several hundred carbohydrate chains attached to the peptide by $\mathrm{O}$ glycosidic linkages between $\mathrm{N}$-acetylgalactosamine and a hydroxylated amino acid. Very often, the carbohydrate chains are clustered in glycosylated domains. Apomucins, which correspond to their peptide part, are encoded by at least six different genes (MUC1, MUC2, MUC4, MUC5B, MUC5AC and MUC7). However, the carbohydrate chains that cover these peptides are highly variable. Given the structural diversity of these carbohydrates as well as their location at airway surfaces, mucins may be involved in interactions with inhabiting microorganisms. The expression of at least two of these genes (MUC2 and MUC5AC) have been shown to be inducible by bacterial products, tobacco smoke and different cytokines [77].

The ASL in CF lungs of children has been shown to be abnormally acidic [81]. Alaiwa et al. [81], in 2014 found that in neonates with CF, nasal ASL (pH $5.2 \pm 0.3$ ) was more acidic than in non-CF neonates ( $\mathrm{pH} 6.4 \pm 0.2)$. Opinions vary about whether ASL $\mathrm{pH}$ remains abnormally acidic with age [82]. In CF mouse model the decreased $\mathrm{HCO}_{3}^{-}$secretion due to CFTR defect and the unchecked $\mathrm{H}^{+}$secretion by the non-gastric $\mathrm{H}^{+} / \mathrm{K}^{+}$adenosine triphosphatase (ATP12A) acidifies ASL [50]. Experiments using CF primary airway epithelial cells stimulated with forskolin and 3-isobutyl-1-methylxanthine demonstrated that between $\mathrm{HCO}_{3}^{-}$and $\mathrm{pH}$, it is the $\mathrm{pH}$ that affects the ASL viscosity more significantly [83]. It was suggested that the decreased $\mathrm{pH}$ probably affected di-sulfide bonds in mucins, thus stabilizing them and resulting in increased viscosity. More importantly, the acidification of ASL impairs airway host defenses, allowing microorganisms to thrive in the CF lung [50, 84].

Micro-rheological properties of CF sputum [85] have been investigated using techniques such as diffusion rates or behavior of a tracer (molecules, peptides, nanospheres and microspheres) using fluorescence recovery after photobleaching, dynamic light scattering, fluorescence correlation spectroscopy and single-particle tracking in multi-particle tracking experiments [86]. These experiments and biochemical analyses have demonstrated that sputum microstructure is significantly altered by elevated mucin and extracellular DNA content. Apart from bacterial infection, the presence of airway proteases and airway remodeling, which occur as the disease progresses, may also affect mucus properties and further alter mucociliary transport and bring about pulmonary inflammation. As CF lung disease progresses, the sticky mucus formed generates microaerobic or even anaerobic settings within the normally aerobic environment [87]. Such a lung environment of reduced oxygen level contributes to persistence of infection and decline of lung function [88, 89].

In addition to being an important factor in CF pathophysiology, CF sputum has been a key source of information on lung microbiome and disease state. Sputum analysis is a non-invasive alternative to bronchoalveolar lavage for obtaining airway secretions and has proven to be a reproducible and practical method for assessing airway inflammation and infection in adults.

\section{The airway microbiota and Pseudomonas aeruginosa Pseudomonas aeruginosa in cystic fibrosis lung disease} $P$. aeruginosa colonization of the airways and infection remain the most important contributor to CF morbidity 
and mortality. While the CFTR defect results in myriad respiratory problems for the patient, the most important clinical feature is the chronic pulmonary infection with $P$. aeruginosa. Ultimately, more than $80 \%$ of patients with CF succumb to respiratory failure brought onto by chronic bacterial infection and concomitant airway inflammation.

P. aeruginosa is a Gram-negative aerobic to facultative anaerobic rod with a ubiquitous presence in the environment. It is well equipped with virulence systems such as toxin secretion systems for overcoming host defenses and inter-bacterial competition. It is capable of forming a well-organized bacterial consortium known as biofilm in the host. In CF, where the host immune response is compromised, $P$. aeruginosa presents itself as a dreadful threat and leads to a progressive decline in lung function.

There is still little clarity concerning acquisition of Pseudomonas in CF. Earlier studies pointed to clinical exposures and social interaction as zones for the acquisition of $P$. aeruginosa. These studies suggested that $P$. aeruginosa spreads by cross-infection [90-92]. The other identified risk factors in the acquisition of $P$. aeruginosa include gender, with females having more predilection than males, while F508del homozygous genotype and co-infection with other pathogens such as $S$. aureus and B. cenocepacia are also independent risk factors [93].

Despite having a low acquisition rate of just $1-2 \%$ per year, about $80 \%$ of patients are chronically colonized by $P$. aeruginosa by the age of $20[94,95]$. In one study, the 8-year risk of death was found to be 2.6 times higher in patients having $P$. aeruginosa than in those without it [96]. Koch [97] suggested a "continuum for $P$. aeruginosa colonization" where the numbers of $P$. aeruginosa goes on increasing until there is "a point of no return". The phase is marked by expression of biofilm forming genes in $P$. aeruginosa and appearance of host biomarkers such as antibodies against $P$. aeruginosa, an increase in polymorphonuclear leucocytes [PMN] and increased serine proteinases [97].

$P$. aeruginosa must overcome challenges such as osmotic stress, competition from other colonizers, nutritional inadequacy, antibiotics, oxidative stresses, etc. in order to sustain and survive in the CF lungs. It characteristically overcomes these challenges by switching its gene expression [98]. During the course of CF lung colonization, it has been demonstrated that $P$. aeruginosa undergoes a life-style change to adapt to the CF environment. Chronic colonization is associated with genotypic and phenotypic changes in the bacterium such as increased antibiotic resistance, decreased metabolism, and slower growth rate, lack of motility, deficient quorum sensing and overproduction of alginate [Fig. 4] [90, 91, 93, 99-101]. Studies by others and by our laboratory have showed that $P$. aeruginosa switches from early acute infection to chronic, biofilm-associated infection by the activities of central regulatory systems such as the Gac-RsmA pathway [98, 102, 103]. A set of genes, especially those related to virulence factors and pathogenicity are turned on or off in response to the host environment to establish chronic infection. Preventing the chronic colonization of $P$. aeruginosa is very significant in avoiding associated lung function decline and development of resistance. Once established, $P$. aeruginosa chronic infection becomes almost impossible to eradicate although "seasonal" airway presence can take place with periods of re-infection and colonization [104]. The colonization may occur by the same strain, and in approximately $25 \%$ of the cases the colonization occurs by the similar genotype $[105,106]$. In addition to gene expression switches, another explanation for changes in $P$. aeruginosa is the occurrence of parallel subpopulations or "hyper-mutator" strains, the mechanism for which is not well understood.

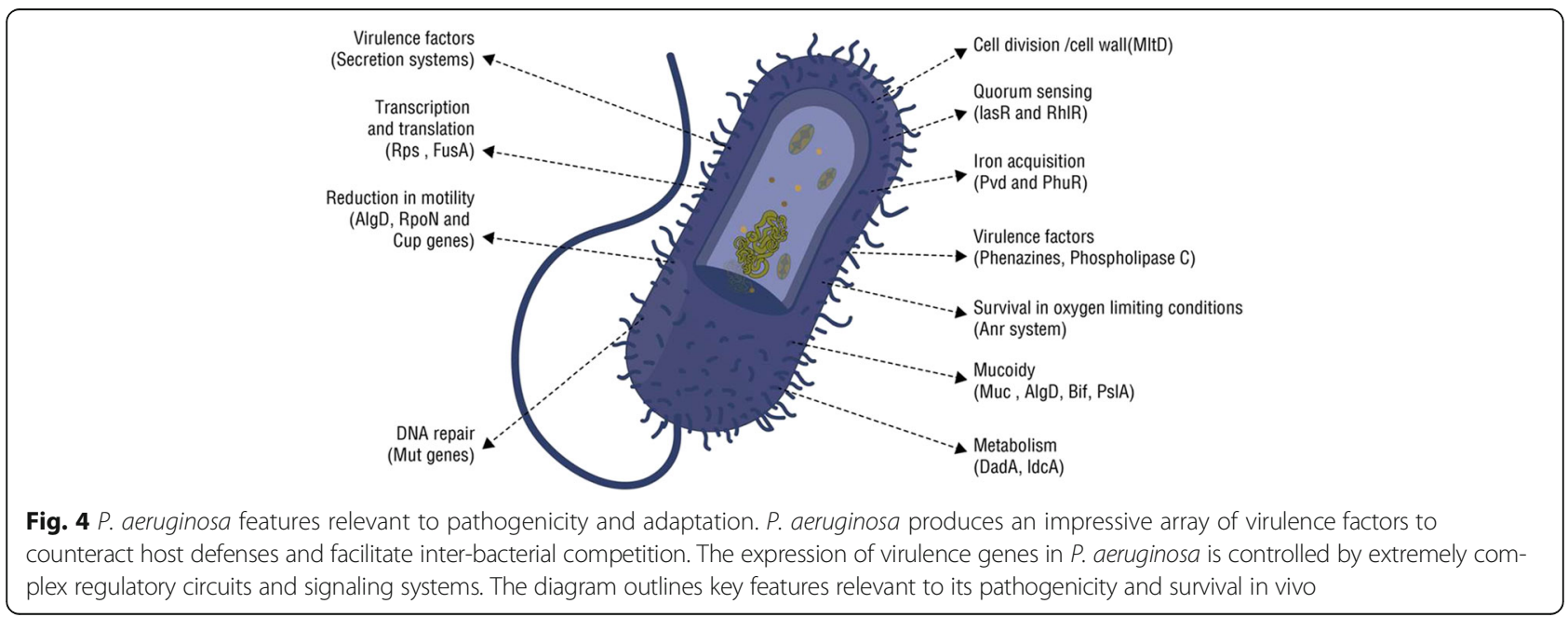


In response to the infection by $P$. aeruginosa, the polymorphonuclear leukocytes (PMNs) release reactive oxygen species (ROS) [107] and reactive nitrogen intermediates which, if able to overwhelm the infecting organism, damage the lipids and proteins inside it. However, if unable to do so, mutations in P. aeruginosa will allow for selection of the variants able to sustain these challenges [108]. One of the most common mutations occurs in mucA encoding anti- $\sigma$-factor that results in mucoid strains [109]. MucA limits the expression of the alginate $(\operatorname{alg} D)$ operon through sequestering RNA polymerase $\sigma$ factor $\sigma^{22}$ encoded by $\operatorname{alg} U . \sigma^{22}$ regulates stress response and is involved in regulation of virulence and motility in P. aeruginosa [107].

Among the other environmental stresses, CF patients often are exposed to a wide variety of antibiotics; thus adaptive resistance to antibiotics is common in $P$. aeruginosa [110]. Interestingly, many genes and regulatory systems involved in antibiotic resistance are often linked to regulation of other genes such as virulence-associated genes as well. Resistance-Nodulation-Cell Division (RND) pumps play important roles in $P$. aeruginosa resistance to antibiotics. There are 12 RND pumps present in the $P$. aeruginosa $\mathrm{PAO} 1$ genome. Results from our lab demonstrated that RND pumps such as MuxABC-OpmB and MexXY-OprM are linked, not only to antimicrobial resistance but to pathogenesis as well in P. aeruginosa [107]. PA0011 in PAO1 was found to be a regulatory gene involved in both carbapenem resistance and virulence in a temperature-regulated manner [107].

Genotypic and phenotypic variants within the $P$. aeruginosa population in CF lung may exist that contribute to different aspects of disease progression and pulmonary exacerbation. Due to the different conditions present in different areas of the respiratory tract, many variants of the same infecting strain may exist and heterogeneity within one population is common in the CF lung [111-113]. The heterogeneity manifests both in terms of genetic and physiological diversity and spatial distributions in the airways. This heterogeneous $P$. aeruginosa population harbors persisters and mutators which are very different from wild type cells and directly complicate therapeutic treatments. The activity and spread of certain subpopulations distributed in the airway niches are implicated in pulmonary exacerbations in CF $[75,76]$.

Though many aspects of chronic colonization by $P$. aeruginosa have been studied, others remain unanswered as to how $P$. aeruginosa overcomes competition by other bacteria to gain predominance? Do the other inhabiting bacteria support or compete with $P$. aeruginosa? What is the role of biofilm dispersal in infection state and disease? An in-depth knowledge of $P$. aeruginosa colonization mechanisms is critical to inform new therapeutic interventions.

\section{Pseudomonas aeruginosa interaction with other bacteria}

Until recently, individual pathogens, such as $P$. aeruginosa and $S$. aureus have been held responsible for CF lung infection and the resulting lung function deterioration. Previous studies in which the senior author of this review participated have shown that the interactions between $P$. aeruginosa, and avirulent oropharyngeal flora bacteria play important roles in disease pathophysiology [114]. Using genome-wide transcriptional analysis, changed expression of around $4 \%$ of genes in P. aeruginosa has been observed in the presence of some other members of the microbiota [115]. Subsequent studies have revealed that previously overlooked bacteria such as Streptococcus milleri group bacteria can cause exacerbations and lung damage in synergy with $P$. aeruginosa $[115,116]$. Now, CF lung infection has been viewed as a polymicrobial infection and Pseudomonas and S. aureus co-infection and competition have been investigated widely in many studies.

It has been shown that colonizing $P$. aeruginosa triggers host cells to produce type-IIA-secreted phospholipase A2, a host enzyme with bactericidal activity capable of inhibiting $S$. aureus [117]. Using co-cultures of $P$. aeruginosa and $S$. aureus on bronchial epithelial cells homozygous for F508del-CFTR, Filkins et al. found that $P$. aeruginosa drives $S$. aureus from aerobic respiration to fermentative metabolism and reduces $S$. aureus viability. This eventually results in the predominance of $P$. aeruginosa in the community [118]. Nguyen et al. [119] recently demonstrated that $P$. aeruginosa not only inhibits the growth of $S$. aureus by regulating free iron levels, but also generates specific 2-alkyl-4 $(1 \mathrm{H})$-quinolones, a class of antimicrobial compounds capable of lysing S. aureus. On the other hand, S. aureus can alter the host immune response to $P$. aeruginosa. It has been observed that $S$. aureus significantly inhibited the IL-8 production stimulated by $P$. aeruginosa and dampened Toll-like receptors (TLR1/TLR2)-mediated activation of the NF- $\mathrm{kB}$ pathway, highlighting the altered inflammatory response in polymicrobial infection [120].

B. cenocepacia infection in CF has been associated with poor prognosis and higher fatalities. Studies have shown that cis-2-dodecenoic acid produced by $B$. cenocepacia, also referred to as a $B$. cenocepacia diffusible signal factor, mediates the cross-talk between $P$. aeruginosa and B. cenocepacia by interference with quorum sensing systems and type three secretion system [121]. P. aeruginosa harbours genome islands with genes that are highly homologous to those found in Burkholderia sp. suggesting that there is a possibility of exchange of genetic material between the two organisms.

Viral infections are associated with pulmonary function decline, antibiotic use, prolonged hospitalizations 
and increased respiratory symptoms [122]. Respiratory syncytial virus is one of the most common viral copathogens in CF [123]. In association with $P$. aeruginosa, respiratory syncytial virus co-infection has been shown to aid $P$. aeruginosa colonization in CF patients [124].

Besides interactions directly affecting pathogenicity and host-pathogen relation, $P$. aeruginosa also interacts with other bacteria in the traditional sense of competition, antagonism and symbiosis affecting the structure and function of the airway microbiota. Iron is essential for both host and inhabiting pathogens, and complex systems of acquisition and utilization have evolved in microorganisms. Nutrient iron is tightly controlled by the host through complicated uptake, storage, and utilization systems, which also serve as a defense mechanism. To sequester iron, the microbes use specific iron-binding molecules known as siderophores [125]. P. aeruginosa not only can produce siderophores e.g. pyoverdine and pyochelin and use them to capture exogenous iron, but also can seize iron-bound mycobactin J, a siderophore produced by Mycobacterium smegmatis [126].

Type VI secretion systems (T6SSs) in $P$. aeruginosa are newly identified contractile nanomachines that transfer effector proteins across eukaryotic and prokaryotic cells and play a pivotal role in $P$. aeruginosa pathogenesis and inter-species competition [127, 128]. The first indication that T6SS could be involved in inter-bacterial interactions came from the identification of three effector proteins that are secreted by the hemolysin coregulated protein secretion island-I-encoded T6SS of $P$. aeruginosa (H1-T6SS) [129]. Each of these three secreted effectors has toxicity towards other bacteria and is encoded adjacent to a gene encoding a product that provides immunity to the toxin, thereby preventing self-intoxication [130]. The effectors can be translocated between bacteria through the T6SS and provide a significant fitness advantage to the donor strain [131].

Clearly, dynamic interactions happen between the pathogens and other microbes in CF lungs. Such interactions not only affect the pathogenicity of the pathogen but also influence the host response, hence modulating the disease progression. Characterization of the complex microbial interactions within the CF airways is critical for understanding $\mathrm{CF}$ lung infection. Interesting questions hereafter arise: can the interaction/communication between different pathogens and other bacteria be used as a new antibacterial target and is it possible to manipulate such interaction to inhibit or disperse pathogens?

\section{The cystic fibrosis airway microbiome}

The earliest knowledge of CF airway microbiota depended on cultivability of the isolated microbes. Newer culture enrichment techniques enable gathering some of the missing information in the lung microbiota [132]. However, increasing studies use the non-culture-based, $16 \mathrm{~S}$ rRNA metagenomic and meta-transcriptomic methods to decipher the complex microbiome in CF lungs. The earlier focus of respiratory microbiome studies was directed towards identifying bacterial members but later, investigations also characterized fungal and viral communities in $\mathrm{CF}$ and how interactions among these communities contributed to CF disease [133-136].

The airways present as a highly structured environment with varying niches which facilitates microbial diversity and fitness selection. Microorganisms adapting to such a dynamic environment can become either specialists or generalists for survival [108]. The microbiome of the lungs more closely resembles that of the oropharynx than the nasopharynx, and the gastrointestinal tract probably through hematogenous spread $[137,138]$. Over 1000 microbial species (viruses, bacteria, moulds and fungi) have been identified in the airways of CF patients. Among them, bacteria typically made up more than 99\% of the microbial community, while viruses and fungi constituted around 1\% [139]. Although gut dysbiosis is an important feature of CF disease [140], the presence and composition of a symbiotic microbiome in human airways are still to be determined despite that recent researches suggested a disrupted respiratory microbiome in CF [141]. Significant associations have been discovered between age and diet and patterns of respiratory colonization, pointing to relations between intestinal microbiota, immune development, and respiratory microbiota in CF.

The pathogenic bacteria associated with $C F$ include $P$. aeruginosa, $H$. influenzae, S. aureus and B. cepacia complex. Many studies have identified other taxa belonging to the genus Prevotella, Streptococcus, Rothia, Actinomyces and Veillonella as well. The emerging pathogens of clinical significance are listed in Table 1. Many of these often benignly colonize the upper respiratory tract (e.g., non-typeable $H$. influenzae or $S$. aureus) or are common environmental organisms that behave as pathogens only under certain conditions such as immunodeficiency.

Interestingly, studies have found a trend of succession in the infecting organisms. S. aureus and $H$. influenzae are the most common bacteria isolated from the sputum in the first decade of life and $P$. aeruginosa is found to dominate numerically in the second and third decades of life [142]. This, however, is changing slowly [143] (Fig. 5), probably due to development of new therapies to control $P$. aeruginosa infection. The rate of multidrug resistant $P$. aeruginosa in CF lungs, however, has been observed to be on a rise (Fig. 6). This suggests that $P$. aeruginosa can adapt well to incoming stressors, specifically antibiotics [142, 144].

Fungi and yeasts have also been identified as critical components of lung microbiome. Middleton et al. have 
Table 1 Emerging pathogenic species in CF respiratory microbiome

\begin{tabular}{ll}
\hline Species & References \\
\hline Stenotrophomonas maltophilia & Waters et al., 2011 [209] \\
$\begin{array}{l}\text { Methicillin resistant Staphylococcus } \\
\text { aureus (MRSA) }\end{array}$ & $\begin{array}{l}\text { Dasenbrook et al., 2008 [210] } \\
\text { Chmiel et al., 2014 [211] }\end{array}$ \\
Mycobacterium abscessus & Malouf et al., 1999 [212] \\
& Binder et al., 2013 [213] \\
& Mahenthiralingam et al., 2014 [214] \\
Achromobacter spp. & Zemanick et al., 2011 [215] \\
Streptococcus milleri & Tunney et al., 2008 [216] \\
& Sibley et al., 2006 [116] \\
Aspergillus fumigatus & Sibley et al., 2010 [217] \\
& Rabin et al., 2012 [218] \\
Sibley et al., 2006 [116] & Stevens et al., 2016 [219] \\
Nocardia spp. & Speirs et al., 2012 [220] \\
Scedosporium apiospermum spp. & Heirali et al., 2016 [221] \\
Rasamsonia argillacea spp. & Parize et al.,2014 [146] \\
Lomentospora prolificans & Mouhajir et al., 2016 [148] \\
(Scedosporium prolificans) & Pihet M et al., 2009 [147] \\
Exophiala dermatitidis & Horré et al.,2010 [223] \\
\hline
\end{tabular}

reported associations between Aspergillus and Candida in the sputum of CF patients and worsened lung function. [145]. Given the small size of fungal spores, an inhalation allows easy access to bronchioles and alveoli where they can germinate and form hyphae. Poor clinical status seems to be associated with reduced fungal biodiversity and species richness [133]. Aspergillus fumigatus, species of the Scedosporium apiospermum complex [146], Aspergillus terreus and Candida albicans are commonly isolated from CF respiratory samples. Other fungal species including $A$. flavus and $A$. nidulans have been isolated transiently while Exophiala dermatitidis and Lomentospora prolificans (formerly Scedosporium prolificans) may chronically colonize the CF airways [147]. Species of the Rasamsonia argillacea complex (initially described as Penicillium emersonii, then as Geosmithia argillacea and finally reassigned to the genus Rasamsonia) [148] and Acrophialophora fusispora have been isolated almost exclusively in the context of CF. Interestingly, most fungal complications in $\mathrm{CF}$ patients have been known to be caused by filamentous fungi, which contribute to the local inflammatory response and cause progressive deterioration of the lung function [147].

Viruses, primarily phages that infect CF pathogens such as Streptococcus, Burkholderia, Mycobacterium, Enterobacteria or Pseudomonas species, have also been described in CF airways [149, 150]. Phages could serve as a means of horizontal transfer of resistance factors between different microbial species. Although no significant difference has been observed in the incidence of viral infections between $\mathrm{CF}$ and healthy controls, there is a marked difference in the severity and length of viral infections in patients with CF [151].

There is no doubt that the progression of CF lung disease relates to CF respiratory microbiota. The complex microbiome challenges our understanding of pulmonary exacerbation and succession of infecting organisms. Fodor et al. [75] employed pyrosequencing to analyze the microbiota in CF patients and found that the

\section{Prevalence of Respiratory Microorganisms, 1988-2014}

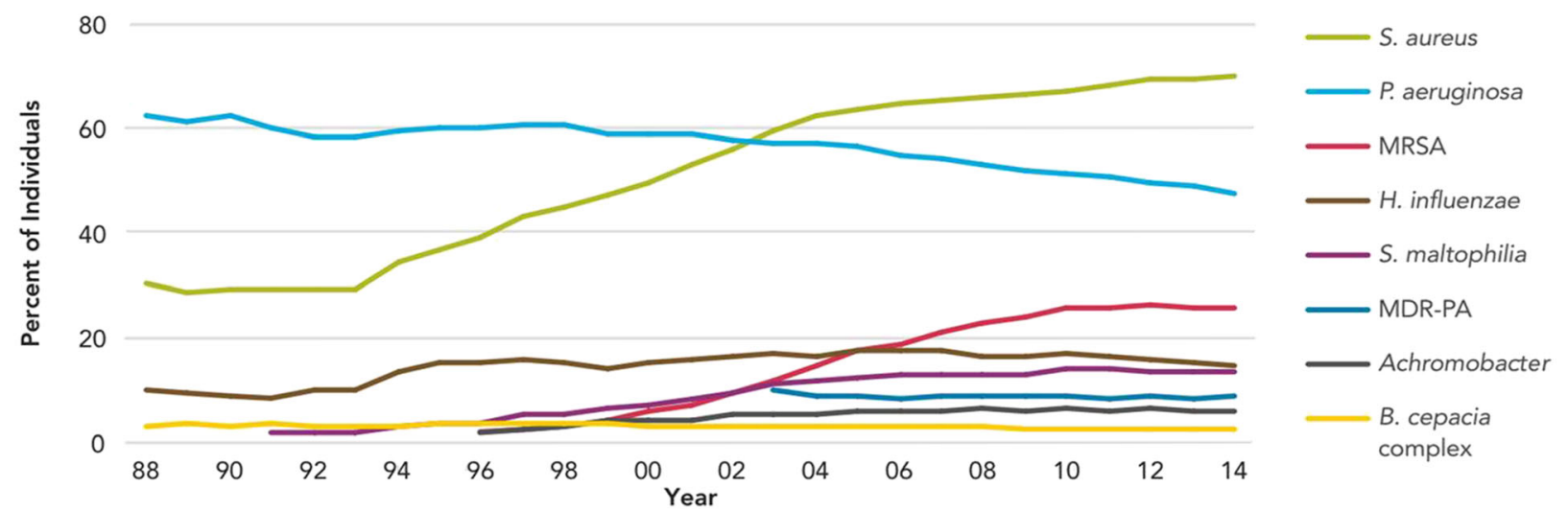

Fig. 5 Prevalence of respiratory pathogens and antimicrobial resistant strains in patients with CF. As of 2003, P. aeruginosa is no longer the most common pathogen cultured in individuals with CF in USA. There has been an observable increase in the prevalence of $S$. aureus and Strenotrophomonas maltophilia. Figure reproduced with permision from Cystic Fibrosis Foundation Patient Registry, Cystic Fibrosis Foundation. Annual Data Report 2014. Bethesda, MD, USA [143] 


\section{Prevalence of Respiratory Microorganisms by Age Cohort, 2014}

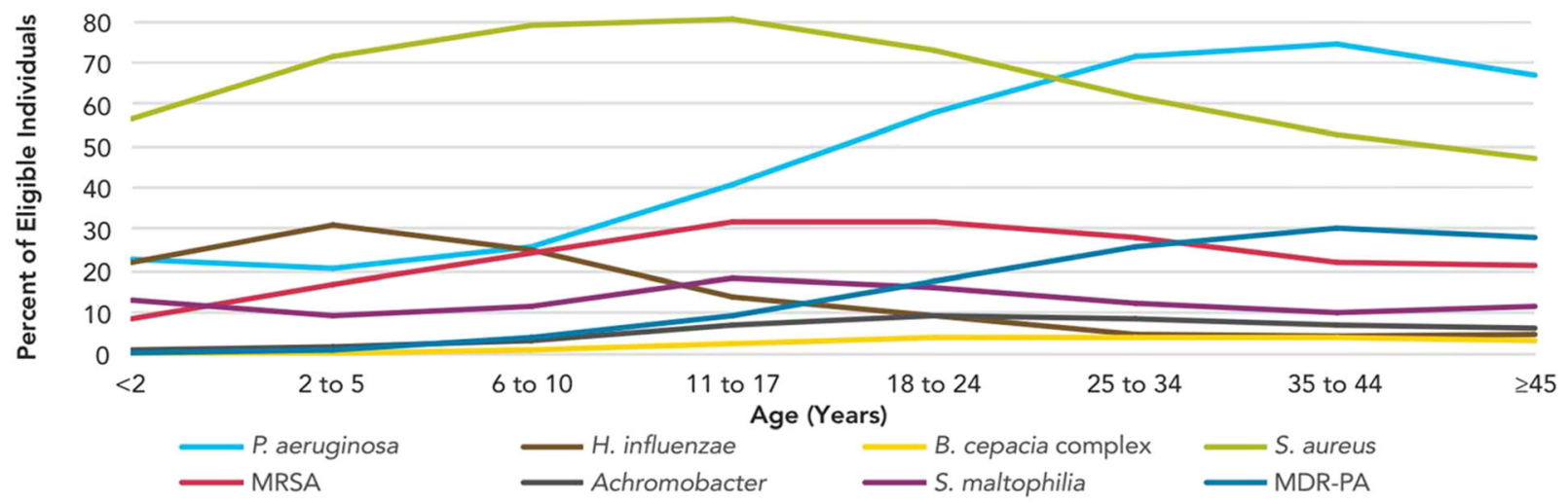

Fig. 6 Prevalence of antimicrobial resistant strains in CF patients. An increase in the rates of multidrug-resistant $P$. aeruginosa infection has been observed in older CF patients in USA. Figure reproduced with permissions from the Cystic Fibrosis Foundation Patient Registry, Cystic Fibrosis Foundation. Annual Data Report 2014. Bethesda, MD, USA [143]

microbial community composition was highly similar in patients during an exacerbation and when clinically stable. They suggested that intrapulmonary spread of infection rather than a change in microbial community composition may cause exacerbations [76]. However, a detailed study of day-to-day stability of the microbiome indicated that although the CF airway microbiota is relatively stable during periods of clinical stability, structural changes do occur which are associated with some, but not all, pulmonary exacerbations [152]. In other cases, an active subgroup of the lung microbiota may cause subtle changes in the microbiota which drive the onset of exacerbations [153]. It is possible that lung environmental alterations such as sub-inhibitory concentrations of antibiotics and host immune factors could cause changes in the virulence factors in the pathogens or changes in the functionality or metabolic activities of the microbiome, triggering exacerbations (Fig. 7).

Human health is a collective reflection of the human body and its associated microbiome. It is significant to review the factors that shape the CF lung microbiome. Although the lungs were classically believed to be sterile, recently published investigations have identified microbial communities in the lungs of healthy humans, and a strong association between markers of inflammatory lung diseases and bacterial community composition has been observed $[154,155]$. Studies have observed a difference in lung microbiome from different climates,

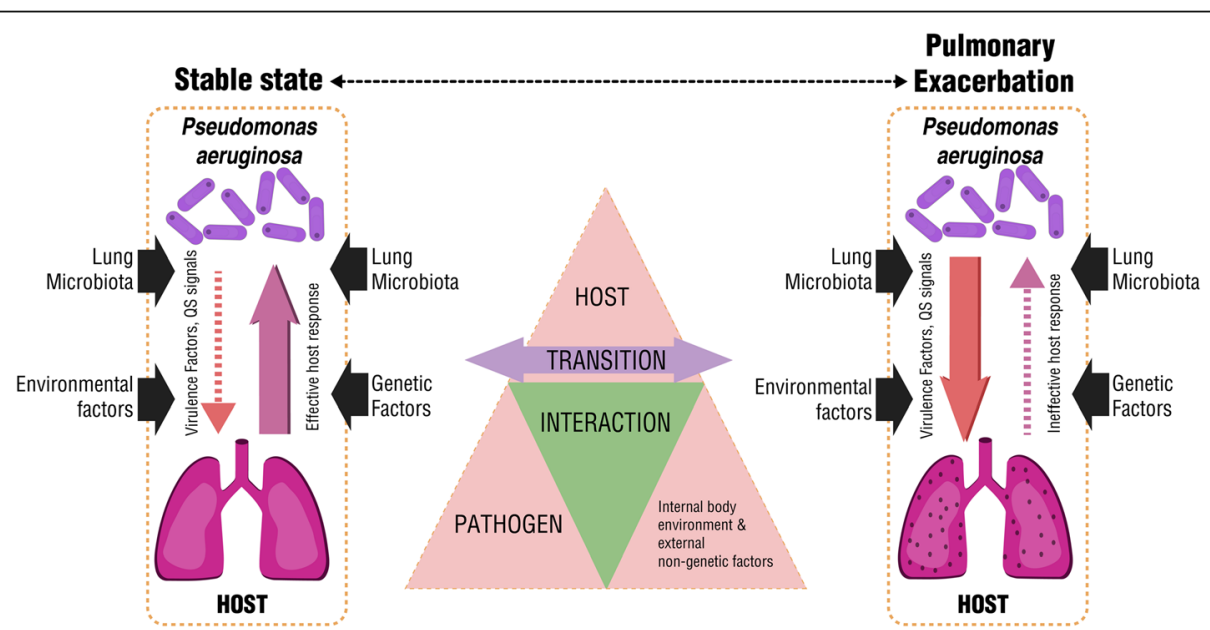

Fig. 7 A potential mechanism of the transition from stable state to pulmonary exacerbation. Without much of a change in bacterial loads, the changes of the pathogenicity triggered by the host environment and/or host-microbiota interaction could lead to a transition from stable state to pulmonary exacerbation 
environmental microbiota, and even household pets. Apart from these factors, the CFTR genotype, the stage of disease and age [156] are among the factors that play a significant role in determining lung microbiome in CF. Alterations in lung environment including presence of antibiotics and changes in host immune responses alter not only bacterial diversity but also the metabolic profiles of inhabiting microflora [150, 157]. As many of the factors that shape the lung microbiome in CF patients differ in individuals the microbiome may be unique. Unlike microbiota in other part of our body, which is believed to have coevolved with humans, CF lung microbiome could show even more diversities among individuals. Nevertheless, it can be expected that future investigation of the CF lung microbiome, especially its structural and functional changes over time, should improve our general understanding of CF, particularly with respect to disease progression, pulmonary exacerbation, host response and antibiotic therapies.

\section{Host immune response in cystic fibrosis lung}

Efficient immune responses are required to protect the host from the harms of invading pathogens. Inflammation is tightly regulated in the host to avoid overshooting and collateral damage. CF lung disease is characterized by chronic and unresolved innate and adaptive responses in the infected airway compartments. Among innate immune cells, neutrophils are the first and predominant cell type transmigrating into $\mathrm{CF}$ airways. In adaptive immunity, T-helper cell type 2 and type 17 cell responses are predominant [158]; however, regulatory $\mathrm{T}$ cell responses are impaired in CF. Beyond these, the immune response in CF lungs is dysregulated at several levels, including impaired ceramide homeostasis, increased apoptosis, autophagy, and macrophage polarization to name a few amongst other deviations, as well discussed by Hart et al. [159].

Phagocytic innate immune cells such as neutrophils and macrophages accumulate within the airway compartments. Unfortunately, they are unable to clear the infecting organisms effectively and the bacteria continue colonizing and forming biofilms (Fig. 8). Neutrophils in CF demonstrate imbalance in ion homeostasis with increased levels of chloride and sodium and decreased levels of magnesium. This results in impaired degranulation and defective phagocytosis [159]. In response to invading pathogens, particularly $P$. aeruginosa, neutrophils accumulate within airways and release powerful antimicrobial compounds, such as neutrophil elastases and myeloperoxidases. Along with nicotinamide adenine dinucleotide phosphate oxidase (also from neutrophils), these compounds result in production of reactive oxygen and nitrogen species. Mutated CFTR in the epithelial cells is unable to channel the antioxidants, glutathione [160] and thiocyanate [161] into the airways to counter the oxidative stress. The increased oxidative stress further activates pro-inflammatory cytokines such as IL-8, resulting in hyper-inflammation within the already inflamed airways.

Neutrophils also use their extracellular host defense armamentarium, also known as neutrophil extracellular traps (NETs) [162] and the intracellular stored antimicrobial effector proteins such as defensins and proteases for killing pathogens. NETs are composed of a DNA backbone with entangled histones and neutrophilic granular components. It is suggested that NETs may protect the host cells from unregulated protease activity [163]. Interestingly, NETs have been shown to be inducible by pyocyanin, a toxin and virulence factor secreted by $P$. aeruginosa in a time- and dose-dependent manner [164]. Thus, bacteria may use NET-mediated killing to exacerbate airway inflammation for their own benefit.

The accumulation of mucus in the airway is consequent to neutrophil elastase accumulation, which is a serine protease secreted by neutrophils in their azurophilic granules and macrophages under inflammation. Neutrophil elastase plays a role in degrading bacterial proteins in azurophilic granules. Under normal conditions, neutrophil elastase is blocked by anti-proteinases such as $\alpha 1$-antitrypsin, the secretory leukocyte peptidase inhibitor, and elafin. However, the amount of neutrophil elastase overcomes the blocking anti-proteinases in $\mathrm{CF}$ [165] which can harm pulmonary matrix. Because NE levels correspond positively to neutrophil counts, and IL-8, IL-1ß and matrix metalloproteinase- 9 levels, they are considered a significant marker for predicting CF infection and diseases [153, 166]. In addition, studies have shown that neutrophil elastase is capable of degrading CFTR [165] as well as cell surface receptors such as CD2, CD4, CD8, complement receptor 1 and antigen presentation receptors.

Macrophages function as phagocytes, clearing both pathogens and apoptotic cells through efferocytosis. Macrophages can be classically subdivided into M1 and M2 macrophages. M2 cells are inducible in a T helper type 2 cell-responsive environment and are capable of causing fibrosis and extracellular matrix remodeling. Recognition of pathogens by macrophages is through TLRs. Among TLRs, $P$. aeruginosa has been reported to be sensed through TLR2, TLR4, TLR5 and/or TLR9. $P$. aeruginosa mutants defective in flagella were resistant to TLR activation and thus could survive airway macrophage phagocytosis and killing. TLR-4 is also expressed in neutrophils. It senses bacterial LPS and leads to lysosomal degradation of bacterial LPS. Descamps et al. [167] reported that TLR5 engagement is crucial for bacterial clearance by murine macrophages in vitro and in 


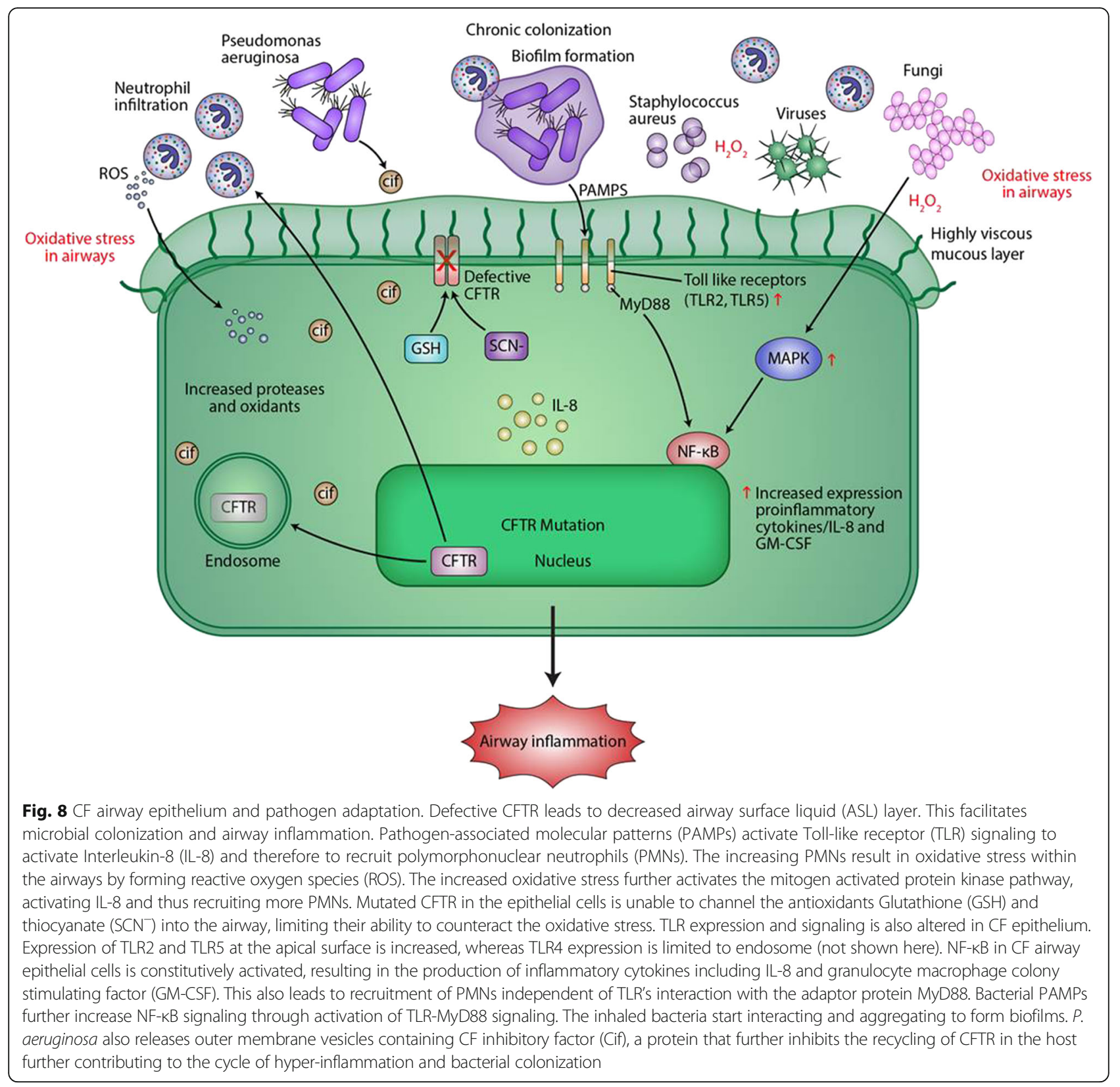

vivo. P. aeruginosa mutants defective in TLR5 activation via flagella were resistant to phagocytosis and killing by airway macrophages. Decreased expression and dysregulation of TLR-4 is found to be a factor for continuous inflammation in CF diseases [110, 168, 169].

In addition to TLRs, another class of strictly intracellular receptors has been described known as Nod-like receptors (NLRs) and NLR family apoptosis inhibitory protein (NAIP). These NLRs and NAIPs react with microbial pathogens-associated molecular patterns (PAMPs) on $P$. aeruginosa to form inflammasomes. NAIP subtypes NAIP-5 and NAIP-6 have been shown to interact with flagellin protein of $P$. aeruginosa [170], whereas the intracellular receptors NAIP2 and NLR family caspase recruitment domains containing protein 4 (NLRC4) also known as IPAF have been shown to interact with the inner rod protein of the type III secretion system in $P$. aeruginosa [171]. Pili from P. aeruginosa have been shown to activate the NLR and NAIP inflammasomes, independently of NLRC4, through an unknown mechanism [172-174]. Cif, a bacterial virulence factor secreted in outer membrane vesicles by $P$. aeruginos $a$, has been shown to increase the ubiquitination and lysosomal degradation of CFTRs. Bomberger et al. [175] have shown that Cif inhibits TAP (transporter associated antigen processing) and major histocompatibility complex (MHC) 
Table $\mathbf{2}$ List of new therapies in CF

\begin{tabular}{|c|c|c|c|}
\hline Type of therapy & Name of the therapy & Benefits of the therapy & References \\
\hline \multirow[t]{2}{*}{$\begin{array}{l}\text { Airway clearance } \\
\text { therapy }\end{array}$} & Dornase-alfa & $\begin{array}{l}\text { Breakdown of excess DNA in cell debris } \\
\text { and mucous of chronically inflamed airways }\end{array}$ & Mogayzel et al., 2013 [224] \\
\hline & Nebulization of hypertonic saline & $\begin{array}{l}\text { Increases airway hydration and mucociliary } \\
\text { clearance }\end{array}$ & Donaldson et al., 2006 [225] \\
\hline \multirow[t]{3}{*}{ Antibiotics therapy } & Tobramycin & Helpful in chronic stages of cystic fibrosis & Mogayzel et al., 2013 [224] \\
\hline & Aztreonam lysinate & $\begin{array}{l}\text { Improves lung function and reduces } \\
\text { incidences of pulmonary exacerbations }\end{array}$ & Assael et al., 2013 [226] \\
\hline & Colistin (colistimethate sodium) & Improves lung function & Schuster et al., 2013 [227] \\
\hline \multirow[t]{2}{*}{$\begin{array}{l}\text { Anti-Inflammatory } \\
\text { therapy }\end{array}$} & Azithromycin & $\begin{array}{l}\text { Macrolide antibiotic. Long term usage in CF } \\
\text { reduces neutrophilic inflammation and } \\
\text { pulmonary exacerbations. Improves lung } \\
\text { function }\end{array}$ & $\begin{array}{l}\text { Uzun et al., } 2014 \text { [228] } \\
\text { Saiman et al., } 2010 \text { [229] }\end{array}$ \\
\hline & Ibuprofen & $\begin{array}{l}\text { Reduces the decline in lung function. } \\
\text { Especially effective in pediatric patients }\end{array}$ & $\begin{array}{l}\text { Lands et al., } 2007 \text { [230] } \\
\text { Mogayzel et al., } 2013 \text { [224] }\end{array}$ \\
\hline Gene therapy & $\begin{array}{l}\text { 1.Zinc finger nucleases } \\
\text { 2.Transcription activator -like effector } \\
\text { nucleases (TALENs) } \\
\text { 3.RNA guide engineered nucleases } \\
\text { (derived from CRISPR) }\end{array}$ & $\begin{array}{l}\text { These nucleases cleave the DNA at a } \\
\text { specific site of interest and allow } \\
\text { genomic modifications }\end{array}$ & $\begin{array}{l}\text { De Boeck et al., } 2014 \text { [231] } \\
\text { Dekkers et al., } 2012 \text { [232] }\end{array}$ \\
\hline CFTR modulation & $\begin{array}{l}\text { 1.Potentiators (VX-770, VX661 Ivacaftor, } \\
\text { Lumacaftor, Riociguat, QBW251). } \\
\text { 2.PTC therapeutics or ataluren }\end{array}$ & $\begin{array}{l}\text { Aimed at correcting the dysfunction of } \\
\text { CFTR like nonsense, frameshift, splice } \\
\text { mutations and non-functional CFTR } \\
\text { mutations. }\end{array}$ & $\begin{array}{l}\text { Van Goor et al., } 2009 \text { [233] } \\
\text { Du et al., } 200862 \\
62 \text { [234] }\end{array}$ \\
\hline
\end{tabular}

class I antigen presentation. In response to the PAMPs and damage-associated molecular patterns from the invading organisms, both epithelial cells and immune cells induce a pro-inflammatory cascade with high level secretion of cytokines and chemokines resulting in lung function decline and lung tissue damage.

Regulatory $\mathrm{T}$ cells $\left(\mathrm{T}_{\text {Reg }}\right)$ are essential for preventing autoimmune diseases, limiting chronic inflammatory diseases, and maintaining immune homeostasis. A decreased in CD4+, CD25+, and FoxP3+ T cells in CF has been observed [169]. Invariant NKT (iNKT) are another special subset of T cells. These iNKT cells express an in-

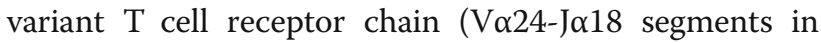
humans) with a beta chain. They can identify glycolipid antigens such as CDId, a highly conserved nonpolymorphic $\mathrm{MHC}$ class I-like molecule. It has been shown by Seigmann et al. [176] that CFTR deficiency in CF mouse models provokes a significant increase of iNKT cells in the lung. Thus, in CF lungs ceramidemediated cell death results in activation of iNKT cells that drive the recruitment of inflammatory cells to the lung tissue, further promoting inflammation and lung tissue injury [176].

Myeloid-derived suppressor cells (MDSCs) balance innate and adaptive immunity by regulating $\mathrm{T}$ cell response in chronic illnesses. It is suggested that $P$. aeruginosa induces the production of MDSCs, and modulates T-cell defense in CF through flagellin [177]. MDSCs accumulate in CF patients with chronic $P$. aeruginosa infection, which may result in the inhibition of $\mathrm{T}$ cell generation and Th17 response, and hence in the protection of $P$. aeruginosa [177].

Human leucocyte antigens-DQ is an MHC class II molecule expressed on dendritic cells, monocytes and macrophages. In CF, there is a reduction in HLA-DQ expression on immune cells in blood and lung [177]. It is speculated that this may be a result of insufficient interferon response; however, the impact of this finding on the development of CF disease is still unknown.

Sputum club cell secretory proteins (CCSPs) are biomarkers of CF disease. These proteins produced by Clara cells possess anti-inflammatory qualities. Previously it was observed that CCSP expression and production are decreased in chronic asthmatic patients [178] and decreased levels of CCSP in broncho-alvelolar lavage fluid were also found in CF patients [179]. Patients with mucoid $P$. aeruginosa variants also had a significantly lower CCSP concentration in sputum. Readers are also referred to review by Cohen and Prince on CCSP [180].

In $\mathrm{CF}$, the repetitive cycle of inflammatory cell recruitment and unregulated immune cell activation causes tissue damage and leads to irreversible loss of lung function. The defect CFTR undermines first line of host defense in the pulmonary system and activates an inflammatory cascade independent of infectious stimuli. Consequently, CF therapeutic intervention relies heavily on antiinflammatory and anti-microbial drugs. However, only partial success for anti-inflammation in CF lung disease has been achieved so far. Recent understanding of the 
connection of human microbiome homeostasis and chronic inflammatory response may have provided another avenue to rebalance the host immune response in CF airways by targeting the CF lung microbiome or restoring a healthy overall human microbiome.

\section{External non-genetic influences in cystic fibrosis}

Though non-genetic factors do not impact the disease pathogenesis directly, they do have an impact on overall outcome of the disease and in overall well-being of a CF patient. Nutrition, exercise, external environment, and psychology can all have significant impact on CF outcomes. Non-genetic influences have been estimated to account for approximately $50 \%$ of the clinical variation in CF [181]. Readers are referred to review by Schechter $[182,183]$ for detailed discussion on these factors. The impact of these factors on above discussed topics is briefly discussed here.

Nutritional status and lung function are highly correlated in CF, and inadequate nutrition is associated with decreased lung function and survival. The precise mechanism of this relationship is unknown but, it has been suggested that malnutrition may impair immunologic defenses against incoming infection and cause respiratory muscle weakness [184]. There may be a role for probiotics in promoting weight gain and controlling inflammatory response in CF children [185]. In retrospect, extensive antibiotic administration in CF may also contribute to weight loss and lethargy.

The hyper-inflammatory response to lung infection in $\mathrm{CF}$ is persistent and generally harmful for the host. Thus, external factors that contribute to the inflammatory response may further damage the already compromised system. Environmental factors, such as exposure to particulate matter, have also been proven to play a role in pulmonary exacerbations and result in decline in the lung function, with ambient air quality for CF patients being especially relevant [186]. Roadside and freeway elements such as industrial pollutants, traffic pollutants, automobile tires, road dust and diesel exhaust have been proven to increase the lung inflammation by increasing the lung cytokines expression [187]. Environmental tobacco smoke is yet another factor which can cause respiratory exacerbation, lung growth impairment in utero and decline in lung function in adults with CF [187]. Cigarette smoke was first reported to inhibit chloride secretion in excised canine tracheas [188], and a dose-dependent association between tobacco smoke exposure and overall disease severity in $\mathrm{CF}$ was observed. Secondary smoke exposure is as harmful as firsthand smoking. In CF it is observed that secondary smoke exposure activates MEK/ERK pathway and disrupts CFTR expression and function [189]. Interestingly, elevated calcium concentration (observed in CF) has also been shown also to activate the MEK/ERK signaling pathway. Secondary smoke exposure has been reported to be associated with isolation of methicillin-resistant $S$. aureus and anaerobic bacteria in oropharyngeal cultures of infants below 12-months of age [190]; these pathogens could have an impact on the composition of lung microbiota in the case of CF patients.

Exercise has been shown to influence lung function positively in CF patients if carried out in a beneficial, safe and monitored environment [191, 192]. Spiritual factors interestingly have been shown to contribute positively on treatment adherence in CF patients [193]. Social behavior factors such as self-esteem and social stigma can also be associated with pulmonary function in CF [194]. Studies have demonstrated the prevalence of anxiety and depression in patients with CF and their parents to be as high as $30 \%$, significantly higher than in the general population $[195,196]$. It has been shown that there are reciprocal connections between a host's social behavior and its microbiome. Considering that social behavior can alter microbiome composition by affecting transmission, it becomes not far-fetched to connect such factors to CF airway microbiome or lung infection. Non-genetic factors can influence the disease outcome; thus, it is important to understand these and intervene accordingly.

\section{Update on therapeutic options}

The last 35 years have seen exciting new developments in antimicrobials, small molecule correctors and CFTR expression enhancers for CF lung disease. However, tackling lung function impairment in CF patients has remained a challenge, and continuing effectors towards either restoring host function (CFTR function and mucociliary clearance) or controlling disease progression (inflammation and infection) are required. Table 2 outlines some of the recent therapeutic approaches in managing CF disease. The classical approach in management of CF involves chest physiotherapy, oxygen therapy, nutritional support, prophylactic and interventional therapy. Bronchodilators such as beta-adrenergic agonists, anticholinergic drugs, and/or theophylline have been shown to help patients with mild overall lung disease. Mucolytics such as dornase alfa and hypertonic saline inhalation have been shown to benefit in CF by increasing hydration of ASL in patients. Corticosteroids have shown several important effects on neutrophil-mediated inflammation; however, the risks involved must be dealt with.

Newer therapies include the use of human mesenchymal stem cells (hMSCs) which are known for their antiinflammatory and antibiotic properties. An in-vivo study on CF lung treated with hMSCs showed significant reduction in the bacterial infection and an increase in the 
production of antimicrobial peptide LL-37. hMSCs have the potential to increase the efficacy of antibiotics and decrease the bacterial growth by releasing soluble products [197]. In addition to the bronchial epithelial cells, nasal airway epithelial cells, intestinal organoids from intestinal stem cell biopsy, monocytes and macrophages have also been studied for CFTR therapy [198, 199].

Genome editing has played an important role in CF studies and it also presents as a promising therapeutic approach. Triplex-forming peptide nucleic acid molecules delivered in nanoparticles have been used successfully to correct F508del CFTR in airway epithelium in vitro [200]. mRNA level editing using oligonucleotides to correct F508del has been evaluated clinically [201]. Gene editing using transcription activator-like effector nucleases (TALENs) or the clustered regularly interspaced short palindromic repeats (CRISPR/Cas9) system has also been explored as a strategy to correct CFTR mutations. However, the exact way in which this might be administered remains to be investigated as it may be argued that the target cells are buried beneath the surface epithelium and may be difficult to access with gene therapy vectors [201-203].

The CFTR potentiator Ivicaftor approved by the Food and Drug Administration in 2012 is an exciting new drug that restores the channel function of CFTR. The drug improves pulmonary functions along with mucociliary clearance and exacerbation in CF patients [204]. Ivacaftor is used for patients with specific CFTR mutations including G551D and several other mutations [204].

Recent years have also seen much advancement in development of new antimicrobials or novel delivery approaches. Leucocytes of Old World monkeys produce cyclic cationic peptides called $\theta$-defensins. Rhesus $\theta$ defensin-1 is known to exhibit anti-bacterial properties against $P$. aeruginosa. A study conducted on a CFTR F508del-homozygous murine model of chronic P. aeruginosa lung infection indicated that treatment with Rhesus $\theta$-defensin-1 significantly decreased lung infection and airway neutrophils [205]. Azithromycin-loaded and rapamycin-loaded nanocomposite microparticles a drypowder-based antibiotic therapy, has been shown to enhance pulmonary antibiotic delivery $[205,206]$. Recently, the use of phages, bacteria-specific viruses that kill pathogens has emerged as a promising alternative. To deal with the problem of pathogenic bacteria developing resistance to phages, pre-adapting phages to bacterial pathogens is used to improve the efficacy of phage therapy both by reducing phage resistance as well as by increasing the phage infectivity. Phage-therapy with pre-adapted or evolved phages have been shown to efficiently decreased the bacterial density of chronic isolates in comparison with the ancestral phages [207]. Phages are easy to develop and can be very specific whereas phage-resistant bacteria remain susceptible to other phages with a similar target range.

Despite all the advances, no isolated therapy is completely effective; combination therapy on the other hand has demonstrated far better efficacy. For example, Lumafactor combined with Ivacaftor improves forced expiratory volume $\left(\mathrm{FEV}_{1}\right)$ and reduces pulmonary exacerbations in F508del CFTR model [208]. In addition to new drugs, integration of comprehensive therapies, technologies, and disease management that are based on holistic understanding of CF pathophysiology, are required.

\section{Conclusions}

Pseudomonas aeruginosa chronic infection is perhaps the most serious problem in CF lung disease. Exploring the pulmonary environment and physiological deviations in $\mathrm{CF}$ is valuable in understanding disease pathogenesis. Though we now recognize $\mathrm{CF}$ as a polymicrobial disease, better understanding of the $\mathrm{CF}$ lung disease requires investigating the $\mathrm{CF}$ airway microbiome, the interactions among the pathogens, the host, the environment and the resulting immune response. The growing knowledge on the complexity of CF airways and the emerging role of sinuses in bacterial persistence has opened up new targets for anti-microbial therapy and thus limiting the chronic infections. We now also know that overshooting of inflammation in CF can support facultative anaerobes, such as $E$. coli and $P$. aeruginosa in inflamed respiratory tracts. Further investigation of bacterial pathogenicity and its regulatory systems, as well as the relationship between host responses and human microbiome should provide novel approaches to control infections in CF. New techniques in enhancing mucociliary clearance and restoring CFTR function will also bring CF patients more effective treatment options.

In addition, pre-term screening, early diagnosis and intervention, counselling, better nutrition, exercise, maintaining favorable external environmental factors such as clean ambient air and limited exposure to potential infection at public places, the availability of multispeciality healthcare systems should help slowing the progression of CF. Big leaps may be expected soon in terms of improving patient health and life.

\section{Abbreviations}

ASL: Airway surface liquid; ATP: Adenosine tri-phosphate; CAMP: Cyclic adenosine monophosphate; CCSP: Club cell secretory protein; CF: Cystic fibrosis; CFTR: Cystic fibrosis transmembrane conductance regulator; hMSC: Human mesenchymal stem cell; ICL: Intracellular loop; IL: Interleukin; iNKT: Invariant natural killer cells; LPS: Lipopolysaccharide; MDSC: Myeloidderived suppressor cell; MHC: Major histocompatibility complex; NAIP: Neuronal apoptosis inhibitory protein; NBD: Nuclear-binding domain; NET: Neutrophil extracellular trap; NLR: Nod-like receptor; NLRC4: NLR family CARD domain containing protein 4; PAMP: Pathogen-associated molecular pattern; PMN: Polymorphonuclear leukocytes; RND: Resistance-nodulationcell division; ROS: Reactive oxygen species; T6SS: Type six secretion system; TLR: Toll-like receptor 


\section{Acknowledgements}

We thank Dr. Colin Dawes for critical reading of the manuscript.

\section{Funding}

This work was supported by grants from the National Science and Engineering Research Council of Canada (Grant No. 402943-2011 RGPIN) and Research Manitoba.

\section{Availability of data and materials}

Not applicable.

\section{Authors' contributions}

AYB and KD conceptualized the work and outlined the manuscript. YL, DS, $\mathrm{MD}$ and SB participated in collecting materials and writing sections of the manuscript. All authors read and approved the final manuscript.

\section{Competing interests}

The authors declare that they have no competing interests.

\section{Consent for publication}

Not applicable.

\section{Ethics approval and consent to participate}

Not applicable.

\begin{abstract}
Author details
${ }^{1}$ Department of Oral Biology, Rady Faculty of Health Sciences, University of Manitoba, 780 Bannatyne Ave, Winnipeg, MB R3E OW2, Canada. ${ }^{2}$ Department of Medical Microbiology, Rady Faculty of Health Sciences, University of Manitoba, 780 Bannatyne Ave, Winnipeg, MB R3E OW2, Canada. ${ }^{3}$ Biology of Breathing Group, Children's Hospital Research Institute of Manitoba, 780 Bannatyne Ave, Winnipeg, MB R3E OW2, Canada.
\end{abstract}

Received: 30 August 2016 Accepted: 24 November 2016 Published online: 05 December 2016

\section{References}

1. Davies JC, Ebdon AM, Orchard C. Recent advances in the management of cystic fibrosis. Arch Dis Child. 2014;99(11):1033-6.

2. Scotet V, Duguépéroux I, Saliou P, Rault G, Roussey M, Audrézet M, Férec C. Evidence for decline in the incidence of cystic fibrosis: a 35-year observational study in Brittany, France. Orphanet J Rare Dis. 2012;7:14.

3. Sawicki GS, Ren CL, Konstan MW, Millar SJ, Pasta DJ, Quittner AL. Treatment complexity in cystic fibrosis: trends over time and associations with sitespecific outcomes. J Cyst Fibros. 2013;12(5):461-7.

4. Dewulf J, Vermeulen F, Wanyama S, Thomas M, Proesmans M, Dupont L, De Boeck K. Treatment burden in patients with at least one class IV or V CFTR mutation. Pediatr Pulmonol. 2015;50(12):1230-6.

5. Sawicki GS, Goss CH. Tackling the increasing complexity of CF care. Pediatr Pulmonol. 2015;50(S40):S74-9.

6. Sawicki GS, Tiddens H. Managing treatment complexity in cystic fibrosis: challenges and opportunities. Pediatr Pulmonol. 2012;47(6):523-33.

7. Cuthbertson L, Rogers GB, Walker AW, Oliver A, Green LE, Daniels TW, Carroll MP, Parkhill J, Bruce KD, Van Der Gast CJ. Respiratory microbiota resistance and resilience to pulmonary exacerbation and subsequent antimicrobial intervention. ISME J. 2015;10:1081-91.

8. Sosnay PR, Siklosi KR, Van Goor F, Kaniecki K, Yu H, Sharma N, Ramalho AS, Amaral MD, Dorfman R, Zielenski J, et al. Defining the disease liability of variants in the cystic fibrosis transmembrane conductance regulator gene. Nat Genet. 2013;45(10):1160-7.

9. Crawford I, Maloney PC, Zeitlin PL, Guggino WB, Hyde SC, Turley H, Gatter KC, Harris A, Higgins CF. Immunocytochemical localization of the cystic fibrosis gene product CFTR. Proc Natl Acad Sci U S A. 1991;88(20):9262-6.

10. Ji HL, Chalfant ML, Jovov B, Lockhart JP, Parker SB, Fuller CM, Stanton BA, Benos DJ. The cytosolic termini of the beta- and gamma-ENaC subunits are involved in the functional interactions between cystic fibrosis transmembrane conductance regulator and epithelial sodium channel. J Biol Chem. 2000;275(36):27947-56.

11. Qadri YJ, Cormet-Boyaka E, Benos DJ, Berdiev BK. CFTR regulation of epithelial sodium channel. Methods Mol Biol. 2011;742:35-50.
12. Nagel G, Szellas T, Riordan JR, Friedrich T, Hartung K. Non-specific activation of the epithelial sodium channel by the CFTR chloride channel. EMBO Rep. 2001;2(3):249-54.

13. Leroy C, Prive A, Bourret JC, Berthiaume Y, Ferraro P, Brochiero E. Regulation of $\mathrm{ENaC}$ and CFTR expression with $\mathrm{K}^{+}$channel modulators and effect on fluid absorption across alveolar epithelial cells. Am J Physiol Lung Cell Mol Physiol. 2006;291(6):L1207-19.

14. Lu M, Leng Q, Egan ME, Caplan MJ, Boulpaep EL, Giebisch GH, Hebert SC. CFTR is required for PKA-regulated ATP sensitivity of Kir1.1 potassium channels in mouse kidney. J Clin Invest. 2006;116(3):797-807.

15. Wang J, Haanes KA, Novak I. Purinergic regulation of CFTR and $\mathrm{Ca}^{2}$ ${ }^{+}$-activated $\mathrm{Cl}^{-}$channels and $\mathrm{K}^{+}$channels in human pancreatic duct epithelium. Am J Physiol Cell Physiol. 2013;304(7):C673-84.

16. Gabriel SE, Clarke LL, Boucher RC, Stutts MJ. CFTR and outward rectifying chloride channels are distinct proteins with a regulatory relationship. Nature. 1993;363(6426):263-6.

17. Egan ME, Schwiebert EM, Guggino WB. Differential expression of ORCC and CFTR induced by low temperature in CF airway epithelial cells. Am J Physiol Lung Cell Mol Physiol. 1995;268(1 Pt 1):C243-51.

18. Fischer H, Illek B, Sachs L, Finkbeiner WE, Widdicombe JH. CFTR and calcium-activated chloride channels in primary cultures of human airway gland cells of serous or mucous phenotype. Am J Physiol Lung Cell Mol Physiol. 2010;299(4):L585-94.

19. Hendrick SM, Mroz MS, Greene CM, Keely SJ, Harvey BJ. Bile acids stimulate chloride secretion through CFTR and calcium-activated $\mathrm{Cl}^{-}$channels in Calu-3 airway epithelial cells. Am J Physiol Lung Cell Mol Physiol. 2014; 307(5):L407-18.

20. Borowitz D. CFTR, bicarbonate, and the pathophysiology of cystic fibrosis. Pediatr Pulmonol. 2015;50 Suppl 40:S24-30.

21. Xie R, Dong X, Wong C, Vallon V, Tang B, Sun J, Yang S, Dong H. Molecular mechanisms of calcium-sensing receptor-mediated calcium signaling in the modulation of epithelial ion transport and bicarbonate secretion. J Biol Chem. 2014;289(50):34642-53.

22. Cheung KH, Leung CT, Leung GP, Wong PY. Synergistic effects of cystic fibrosis transmembrane conductance regulator and aquaporin-9 in the rat epididymis. Reprod Biol Endocrinol. 2003;68(5):1505-10.

23. Clancy JP. Cystic fibrosis transmembrane conductance regulator function in airway smooth muscle. A novel role in cystic fibrosis airway obstruction. Am J Respir Crit Care Med. 2016;193(4):352-3.

24. Mornon JP, Lehn P, Callebaut I. Molecular models of the open and closed states of the whole human CFTR protein. Cell Mol Life Sci. 2009;66(21): 3469-86.

25. Dawson RJ, Locher KP. Structure of a bacterial multidrug $A B C$ transporter. Nature. 2006:443(7108):180-5.

26. Dalton J, Kalid O, Schushan M, Ben-Tal N, Villà-Freixa J. New model of cystic fibrosis transmembrane conductance regulator proposes active channel-like conformation. J Chem Inf Model. 2012;52(7):1842-53.

27. Serohijos AW, Hegedus T, Aleksandrov AA, He L, Cui L, Dokholyan NV, Riordan JR. Phenylalanine-508 mediates a cytoplasmic-membrane domain contact in the CFTR 3D structure crucial to assembly and channel function. Proc Natl Acad Sci U S A. 2008;105(9):3256-61.

28. Harris WT, Kirk KL. CFTR and cystic fibrosis. In: Ion channels and transporters of epithelia in health and disease. Edited by Hamilton KL, Devor DC. New York, NY: Springer New York; 2016: 519-52.

29. Molinski SV, Ahmadi S, Hung M, Bear CE. Facilitating structure-function studies of CFTR modulator sites with efficiencies in mutagenesis and functional screening. J Biomol Screen. 2015;20(10):1204-17.

30. Lewis HA, Zhao X, Wang C, Sauder JM, Rooney I, Noland BW, Lorimer D, Kearins MC, Conners K, Condon B, et al. Impact of the deltaF508 mutation in first nucleotide-binding domain of human cystic fibrosis transmembrane conductance regulator on domain folding and structure. J Biol Chem. 2005; 280(2):1346-53.

31. Vergani P, Lockless SW, Nairn AC, Gadsby DC. CFTR channel opening by ATP-driven tight dimerization of its nucleotide-binding domains. Nature. 2005;433(7028):876-80.

32. Csanády L, Vergani P, Gadsby DC. Strict coupling between CFTR's catalytic cycle and gating of its $\mathrm{Cl}^{-}$ion pore revealed by distributions of open channel burst durations. Proc Natl Acad Sci. 2010;107(3):1241-6.

33. Hwang TC, Sheppard DN. Gating of the CFTR Cl- channel by ATPdriven nucleotide-binding domain dimerisation. J Physiol. 2009:587(Pt 10):2151-61. 
34. Protasevich I, Yang Z, Wang C, Atwell S, Zhao X, Emtage S, Wetmore D, Hunt JF, Brouillette CG. Thermal unfolding studies show the disease causing F508del mutation in CFTR thermodynamically destabilizes nucleotidebinding domain 1. Protein Sci. 2010;19(10):1917-31.

35. Scott-Ward TS, Amaral MD. Deletion of Phe508 in the first nucleotidebinding domain of the cystic fibrosis transmembrane conductance regulator increases its affinity for the heat shock cognate 70 chaperone. FEBS J. 2009;276(23):7097-109.

36. Wang C, Protasevich I, Yang Z, Seehausen D, Skalak T, Zhao X, Atwell S, Spencer Emtage J, Wetmore DR, Brouillette CG, et al. Integrated biophysical studies implicate partial unfolding of NBD1 of CFTR in the molecular pathogenesis of F508del cystic fibrosis. Protein Sci. 2010;19(10):1932-47.

37. Du K, Lukacs GL. Cooperative assembly and misfolding of CFTR domains in vivo. Mol Biol Cell. 2009;20(7):1903-15.

38. Mendoza JL, Schmidt A, Li Q, Nuvaga E, Barrett T, Bridges RJ, Feranchak AP, Brautigam CA, Thomas PJ. Requirements for efficient correction of deltaF508 CFTR revealed by analyses of evolved sequences. Cell. 2012;148(1-2):164-74.

39. Rabeh WM, Bossard F, Xu H, Okiyoneda T, Bagdany M, Mulvihill CM, Du K, Di Bernardo S, Liu Y, Konermann L, et al. Correction of both NBD1 energetics and domain interface is required to restore $\Delta$ F508 CFTR folding and function. Cell. 2012;148(1-2):150-63.

40. Elborn JS. Cystic fibrosis. Lancet. 2016;388(10059);2519-31.

41. Meyerholz DK. Lessons learned from the cystic fibrosis pig. Theriogenology. 2016;86(1):427-32.

42. Denny RA, Gavrin LK, Saiah E. Recent developments in targeting protein misfolding diseases. Bioorg Med Chem Lett. 2013;23(7):1935-44.

43. Esposito S, Tosco A, Villella VR, Raia V, Kroemer G, Maiuri L. Manipulating proteostasis to repair the F508del-CFTR defect in cystic fibrosis. Mol Cell Pediatr. 2016;3(1):13.

44. Rudashevskaya EL, Stockner T, Trauner M, Freissmuth M, Chiba P. Pharmacological correction of misfolding of ABC proteins. Drug Discov Today. 2014;12:e87-94.

45. Pier GB, Grout M, Zaidi TS. Cystic fibrosis transmembrane conductance regulator is an epithelial cell receptor for clearance of Pseudomonas aeruginosa from the lung. Proc Natl Acad Sci U S A. 1997;94(22):12088-93.

46. Jolly AL, Takawira D, Oke OO, Whiteside SA, Chang SW, Wen ER, Quach K, Evans DJ, Fleiszig SMJ. Pseudomonas aeruginosa-induced Bleb-Niche formation in epithelial cells is independent of actinomyosin contraction and enhanced by loss of cystic fibrosis transmembrane-conductance regulator osmoregulatory function. MBio. 2015;6(2):e02533-14.

47. Abdulrahman BA, Khweek AA, Akhter A, Caution K, Tazi M, Hassan H, Zhang $Y$, Rowland PD, Malhotra S, Aeffner F, et al. Depletion of the ubiquitinbinding adaptor molecule SQSTM1/p62 from macrophages harboring cftr $\Delta$ F508 mutation improves the delivery of Burkholderia cenocepacia to the autophagic machinery. J Biol Chem. 2013;288(3):2049-58.

48. Assani K, Tazi MF, Amer AO, Kopp BT. IFN- $y$ stimulates autophagy-mediated clearance of Burkholderia cenocepacia in human cystic fibrosis macrophages. PLoS One. 2014;9(5):e96681.

49. Bruscia EM, Zhang P, Barone C, Scholte BJ, Homer R, Krause DS, Egan ME. Increased susceptibility of $\mathrm{Cftr}^{-1-}$ mice to LPS-induced lung remodeling. Am J Physiol Lung Cell Mol Physiol. 2016;310(8):L711-9.

50. Shah VS, Meyerholz DK, Tang XX, Reznikov L, Abou Alaiwa M, Ernst SE, Karp $\mathrm{PH}$, Wohlford-Lenane $\mathrm{CL}$, Heilmann KP, Leidinger MR, et al. Airway acidification initiates host defense abnormalities in cystic fibrosis mice. Science. 2016:351(6272):503-7.

51. Montaudon M, Berger P, Cangini-Sacher A, De Dietrich G, Tunon-De-Lara $J M$, Marthan R, Laurent F. Bronchial measurement with three-dimensional quantitative thin-section CT in patients with cystic fibrosis. Radiology. 2007; 242(2):573-81.

52. Meyerholz DK, Stoltz DA, Namati E, Ramachandran S, Pezzulo AA, Smith AR, Rector MV, Suter MJ, Kao S, Mclennan G, et al. Loss of cystic fibrosis transmembrane conductance regulator function produces abnormalities in tracheal development in neonatal pigs and young children. Am J Respir Crit Care Med. 2010;182(10):1251-61.

53. Long FR, Williams RS, Castile RG. Structural airway abnormalities in infants and young children with cystic fibrosis. J Pediatr. 2004;144(2):154-61.

54. Wine JJ, Joo NS. Submucosal glands and airway defense. Proc Am Thorac Soc. 2004;1(1):47-53.

55. Engelhardt JF, Yankaskas JR, Ernst SA, Yang Y, Marino CR, Boucher RC, Cohn JA, Wilson JM. Submucosal glands are the predominant site of CFTR expression in the human bronchus. Nat Genet. 1992;2(3):240-8.
56. Basbaum CB, Jany B, Finkbeiner WE. The serous cell. Annu Rev Physiol. 1990; 52(1):97-113.

57. Meyrick B, Reid L. Ultrastructure of cells in the human bronchial submucosal glands. J Anat. 1970;107(Pt 2):281.

58. Meyrick B, Sturgess JM, Reid L. A reconstruction of the duct system and secretory tubules of the human bronchial submucosal gland. Thorax. 1969; 24(6):729-36.

59. Widdicombe JH, Wine JJ. Airway gland structure and function. Physiol Rev. 2015;95(4):1241-319.

60. Ballard ST, Inglis SK. Liquid secretion properties of airway submucosal glands. J Physiol. 2004;556(Pt 1):1-10.

61. Ballard ST, Trout L, Bebok Z, Sorscher EJ, Crews A. CFTR involvement in chloride, bicarbonate, and liquid secretion by airway submucosal glands. Am J Physiol. 1999;277(4 Pt 1):L694-9.

62. Joo NS, Saenz Y, Krouse ME, Wine JJ. Mucus secretion from single submucosal glands of pig. Stimulation by carbachol and vasoactive intestinal peptide. J Biol Chem. 2002;277(31):28167-75.

63. Inglis SK, Corboz MR, Taylor AE, Ballard ST. Effect of anion transport inhibition on mucus secretion by airway submucosal glands. Am J Physiol. 1997;272(2 Pt 1):L372-7.

64. Trout L, Gatzy JT, Ballard ST. Acetylcholine-induced liquid secretion by bronchial epithelium: role of $\mathrm{Cl}^{-}$and $\mathrm{HCO}^{-}$transport. Am J Physiol. 1998; 275(6 Pt 1):L1095-9.

65. Fauvart M, De Groote VN, Michiels J. Role of persister cells in chronic infections: clinical relevance and perspectives on anti-persister therapies. J Med Microbiol. 2011;60(Pt 6):699-709.

66. Lewis K. Persister cells. Annu Rev Microbiol. 2010;64:357-72.

67. Lewis K. Persister cells: molecular mechanisms related to antibiotic tolerance. Handb Exp Pharmacol. 2012;211:121-33.

68. Ferroni A, Guillemot D, Moumile K, Bernede C, Le Bourgeois M, Waernessyckle S, Descamps P, Sermet-Gaudelus I, Lenoir G, Berche P, et al. Effect of mutator Pseudomonas aeruginosa on antibiotic resistance acquisition and respiratory function in cystic fibrosis. Pediatr Pulmonol. 2009;44(8):820-5.

69. Hogardt M, Heesemann J. Microevolution of Pseudomonas aeruginosa to a chronic pathogen of the cystic fibrosis lung. Curr Top Microbiol Immunol. 2013:358:91-118.

70. Oliver A. Mutators in cystic fibrosis chronic lung infection: prevalence, mechanisms, and consequences for antimicrobial therapy. Int J Med Microbiol. 2010;300(8):563-72.

71. Oliver A, Mena A. Bacterial hypermutation in cystic fibrosis, not only for antibiotic resistance. Clin Microbiol Infect. 2010;16(7):798-808.

72. Warren $A E$, Boulianne-Larsen $C M$, Chandler $C B$, Chiotti $K$, Kroll E, Miller SR, Taddei F, Sermet-Gaudelus I, Ferroni A, Mcinnerney K, et al. Genotypic and phenotypic variation in Pseudomonas aeruginosa reveals signatures of secondary infection and mutator activity in certain cystic fibrosis patients with chronic lung infections. Infect Immun. 2011;79(12):4802-18.

73. López-Causapé C, Rojo-Molinero E, Macià MD, Oliver A. The problems of antibiotic resistance in cystic fibrosis and solutions. Expert Rev Respir Med. 2015;9(1):73-88

74. Boutin S, Graeber SY, Weitnauer M, Panitz J, Stahl M, Clausznitzer D, Kaderali L, Einarsson G, Tunney MM, Elborn JS, et al. Comparison of microbiomes from different niches of upper and lower airways in children and adolescents with cystic fibrosis. PLoS One. 2015;10(1):e0116029.

75. Fodor AA, Klem ER, Gilpin DF, Elborn JS, Boucher RC, Tunney MM, Wolfgang MC. The adult cystic fibrosis airway microbiota is stable over time and infection type, and highly resilient to antibiotic treatment of exacerbations. PLoS One. 2012;7(9):e45001.

76. Whelan FJ, Surette MG. Clinical insights into pulmonary exacerbations in cystic fibrosis from the microbiome. What are we missing? Ann Am Thorac Soc. 2015;12 Suppl 2:S207-11.

77. Lamblin G, Degroote S, Perini JM, Delmotte P, Scharfman A, Davril M, LoGuidice JM, Houdret N, Dumur V, Klein A, et al. Human airway mucin glycosylation: a combinatory of carbohydrate determinants which vary in cystic fibrosis. Glycoconj J. 2001;18(9):661-84.

78. Quinn RA, Lim YW, Maughan H, Conrad D, Rohwer F, Whiteson KL. Biogeochemical forces shape the composition and physiology of polymicrobial communities in the cystic fibrosis lung. MBio. 2014;5(2): e00956-00913.

79. Huffnagle GB, Dickson RP. The bacterial microbiota in inflammatory lung diseases. Clin Immunol. 2015;159(2):177-82. 
80. Boucher RC, Cotton CU, Gatzy JT, Knowles MR, Yankaskas JR. Evidence for reduced $\mathrm{Cl}^{-}$and increased $\mathrm{Na}^{+}$permeability in cystic fibrosis human primary cell cultures. J Physiol. 1988;405:77-103.

81. Abou Alaiwa MH, Beer AM, Pezzulo AA, Launspach JL, Horan RA, Stoltz DA Starner TD, Welsh MJ, Zabner J. Neonates with cystic fibrosis have a reduced nasal liquid pH; a small pilot study. J Cyst Fibros. 2014;13(4):373-7.

82. Mcshane D, Davies JC, Davies MG, Bush A, Geddes DM, Alton EW. Airway surface pH in subjects with cystic fibrosis. Eur Respir J. 2003;21(1):37-42.

83. Tang XX, Ostedgaard LS, Hoegger MJ, Moninger TO, Karp PH, Mcmenimen JD, Choudhury B, Varki A, Stoltz DA, Welsh MJ. Acidic pH increases airway surface liquid viscosity in cystic fibrosis. J Clin Invest. 2016;126(3):879-91.

84. Pezzulo AA, Tang XX, Hoegger MJ, Alaiwa MH, Ramachandran S, Moninger TO, Karp PH, Wohlford-Lenane CL, Haagsman HP, Van Eijk M, et al. Reduced airway surface $\mathrm{pH}$ impairs bacterial killing in the porcine cystic fibrosis lung. Nature. 2012:487(7405):109-13.

85. Stigliani M, Manniello MD, Zegarra-Moran O, Galietta L, Minicucci L, Casciaro R, Garofalo E, Incarnato L, Aquino RP, Del Gaudio P. Rheological properties of cystic fibrosis bronchial secretion and in vitro drug permeation study: the effect of sodium bicarbonate. J Aerosol Med Pulm Drug Deliv. 2016;29(4): 337-45.

86. Lai SK, Wang YY, Wirtz D, Hanes J. Micro and macrorheology of mucus. Adv Drug Del Rev. 2009;61(2):86-100.

87. Worlitzsch D, Tarran R, Ulrich M, Schwab U, Cekici A, Meyer KC, Birrer P, Bellon G, Berger J, Weiss T, et al. Effects of reduced mucus oxygen concentration in airway Pseudomonas infections of cystic fibrosis patients. J Clin Invest. 2002;109(3):317-25.

88. Leeper-Woodford SK, Detmer K. Acute hypoxia increases alveolar macrophage tumor necrosis factor activity and alters NF-kB expression. Am J Physiol Lung Cell Mol Physiol. 1999;276(6 Pt 1):L909-16.

89. Borriello G, Werner E, Roe F, Kim AM, Ehrlich GD, Stewart PS. Oxygen limitation contributes to antibiotic tolerance of Pseudomonas aeruginosa in biofilms. Antimicrob Agents Chemother. 2004;48(7):2659-64.

90. Zimakoff J, Hoiby N, Rosendal K, Guilbert JP. Epidemiology of Pseudomonas aeruginosa infection and the role of contamination of the environment in a cystic fibrosis clinic. J Hosp Infect. 1983;4(1):31-40.

91. Zembrzuska-Sadkowska E, Sneum M, Ojeniyi B, Heiden L, Hoiby N. Epidemiology of Pseudomonas aeruginosa infection and the role of contamination of the environment in the danish cystic fibrosis centre. J Hosp Infect. 1995;29(1):1-7.

92. Farrell PM, Shen G, Splaingard M, Colby CE, Laxova A, Kosorok MR, Rock MJ, Mischler EH. Acquisition of Pseudomonas aeruginosa in children with cystic fibrosis. Pediatrics. 1997;100(5):E2.

93. Maselli JH, Sontag MK, Norris JM, Mackenzie T, Wagener JS, Accurso FJ. Risk factors for initial acquisition of Pseudomonas aeruginosa in children with cystic fibrosis identified by newborn screening. Pediatr Pulmonol. 2003; 35(4):257-62.

94. Koch C. Early infection and progression of cystic fibrosis lung disease. Pediatr Pulmonol. 2002;34(3):232-6.

95. Tingpej P, Smith L, Rose B, Zhu H, Conibear T, Al Nassafi K, Manos J, Elkins $M$, Bye P, Willcox M, et al. Phenotypic characterization of clonal and nonclonal Pseudomonas aeruginosa strains isolated from lungs of adults with cystic fibrosis. J Clin Microbiol. 2007;45(6):1697-704.

96. Emerson J, Rosenfeld M, Mcnamara S, Ramsey B, Gibson RL. Pseudomonas aeruginosa and other predictors of mortality and morbidity in young children with cystic fibrosis. Pediatr Pulmonol. 2002;34(2):91-100.

97. Hudson VL, Wielinski CL, Regelmann WE. Prognostic implications of initial oropharyngeal bacterial flora in patients with cystic fibrosis diagnosed before the age of two years. J Pediatr. 1993;122(6):854-60.

98. Goodman AL, Kulasekara B, Rietsch A, Boyd D, Smith RS, Lory S. A signaling network reciprocally regulates genes associated with acute infection and chronic persistence in Pseudomonas aeruginosa. Dev Cell. 2004;7(5):745-54.

99. Del Campo R, Morosini MI, De La Pedrosa EG, Fenoll A, Munoz-Almagro C, Maiz L, Baquero F, Canton R. Population structure, antimicrobial resistance, and mutation frequencies of Streptococcus pneumoniae isolates from cystic fibrosis patients. J Clin Microbiol. 2005;43(5):2207-14.

100. Nixon GM, Armstrong DS, Carzino R, Carlin JB, Olinsky A, Robertson CF, Grimwood K. Clinical outcome after early Pseudomonas aeruginosa infection in cystic fibrosis. J Pediatr. 2001;138(5):699-704

101. Mccarthy RR, Mooij MJ, Reen FJ, Lesouhaitier O, O'gara F. A new regulator of pathogenicity $(b v / R)$ is required for full virulence and tight microcolony formation in Pseudomonas aeruginosa. Microbiology. 2014;160(Pt 7):1488-500.
102. Kong W, Chen L, Zhao J, Shen T, Surette MG, Shen L, Duan K. Hybrid sensor kinase PA1611 in Pseudomonas aeruginosa regulates transitions between acute and chronic infection through direct interaction with RetS. Mol Microbiol. 2013;88(4):784-97.

103. Ventre I, Goodman AL, Vallet-Gely I, Vasseur P, Soscia C, Molin S, Bleves S, Lazdunski A, Lory S, Filloux A. Multiple sensors control reciprocal expression of Pseudomonas aeruginosa regulatory RNA and virulence genes. Proc Natl Acad Sci U S A. 2006;103(1):171-6.

104. Munck A, Bonacorsi S, Mariani-Kurkdjian P, Lebourgeois M, Gerardin M, Brahimi N, Navarro J, Bingen E. Genotypic characterization of Pseudomonas aeruginosa strains recovered from patients with cystic fibrosis after initial and subsequent colonization. Pediatr Pulmonol. 2001;32(4):288-92.

105. Johansen HK, Hoiby N. Seasonal onset of initial colonisation and chronic infection with Pseudomonas aeruginosa in patients with cystic fibrosis in Denmark. Thorax. 1992;47(2):109-11.

106. Kolpen M, Hansen CR, Bjarnsholt T, Moser C, Christensen LD, Van Gennip M, Ciofu O, Mandsberg L, Kharazmi A, Doring G, et al. Polymorphonuclear leucocytes consume oxygen in sputum from chronic Pseudomonas aeruginosa pneumonia in cystic fibrosis. Thorax. 2009;65(1):57-62

107. Yang $L$, Chen $L$, Shen $L$, Surette $M$, Duan K. Inactivation of MuxABC-OpmB transporter system in Pseudomonas aeruginosa leads to increased ampicillin and carbenicillin resistance and decreased virulence. J Microbiol. 2011;49(1):107-14.

108. Hauser AR, Jain M, Bar-Meir M, Mccolley SA. Clinical significance of microbial infection and adaptation in cystic fibrosis. Clin Microbiol Rev. 2011;24(1):29-70.

109. Wood LF, Ohman DE. Identification of genes in the $\sigma^{22}$ regulon of Pseudomonas aeruginosa required for cell envelope homeostasis in either the planktonic or the sessile mode of growth. MBio. 2012;3(3):e00094-00012.

110. Wu D, Wang J, Zhang M. Altered Th17/Treg ratio in nasal polyps with distinct cytokine profile: association with patterns of inflammation and mucosal remodeling. Medicine. 2016;95(10):e2998.

111. Tai AS, Bell SC, Kidd TJ, Trembizki E, Buckley C, Ramsay KA, David M, Wainwright CE, Grimwood K, Whiley DM. Genotypic diversity within a single Pseudomonas aeruginosa strain commonly shared by australian patients with cystic fibrosis. PLoS One. 2015;10(12):e0144022.

112. Workentine ML, Sibley CD, Glezerson B, Purighalla S, Norgaard-Gron JC, Parkins MD, Rabin HR, Surette MG. Phenotypic heterogeneity of Pseudomonas aeruginosa populations in a cystic fibrosis patient. PLoS One. 2013:8(4):e60225.

113. Feliziani S, Marvig RL, Luján AM, Moyano AJ, Di Rienzo JA, Krogh Johansen $\mathrm{H}$, Molin S, Smania AM. Coexistence and within-host evolution of diversified lineages of hypermutable Pseudomonas aeruginosa in long-term cystic fibrosis infections. PLoS Genet. 2014;10(10):e1004651.

114. Duan K, Dammel C, Stein J, Rabin H, Surette MG. Modulation of Pseudomonas aeruginosa gene expression by host microflora through interspecies communication. Mol Microbiol. 2003;50(5):1477-91.

115. Sibley CD, Duan K, Fischer C, Parkins MD, Storey DG, Rabin HR, Surette MG. Discerning the complexity of community interactions using a drosophila model of polymicrobial infections. PLoS Pathog. 2008;4(10):e1000184.

116. Sibley CD, Rabin H, Surette MG. Cystic fibrosis: a polymicrobial infectious disease. Future Microbiol. 2006;1(1):53-61.

117. Pernet E, Guillemot L, Burgel PR, Martin C, Lambeau G, Sermet-Gaudelus I, Sands D, Leduc D, Morand PC, Jeammet $L$, et al. Pseudomonas aeruginosa eradicates Staphylococcus aureus by manipulating the host immunity. Nat Commun. 2014,5:5105

118. Filkins LM, Graber JA, Olson DG, Dolben EL, Lynd LR, Bhuju S, O'toole GA. Coculture of Staphylococcus aureus with Pseudomonas aeruginosa drives $S$. aureus towards fermentative metabolism and reduced viability in a cystic fibrosis model. J Bacteriol. 2015;197(14):2252-64.

119. Nguyen AT, Jones JW, Ruge MA, Kane MA, Oglesby-Sherrouse AG. Iron depletion enhances production of antimicrobials by Pseudomonas aeruginosa. J Bacteriol. 2015;197(14):2265-75.

120. Chekabab SM, Silverman RJ, Lafayette SL, Luo Y, Rousseau S, Nguyen D. Staphylococcus aureus inhibits IL-8 responses induced by Pseudomonas aeruginosa in airway epithelial cells. PLoS One. 2015;10(9):e0137753.

121. Deng Y, Boon C, Chen S, Lim A, Zhang LH. Cis-2-dodecenoic acid signal modulates virulence of Pseudomonas aeruginosa through interference with quorum sensing systems and T3SS. BMC Microbiol. 2013;13:231.

122. Stroobant J. Viral infection in cystic fibrosis. J R Soc Med. 1986;79 Suppl 12:19-22.

123. Wat D, Gelder C, Hibbitts S, Cafferty F, Bowler I, Pierrepoint M, Evans R, Doull I. The role of respiratory viruses in cystic fibrosis. J Cyst Fibros. 2008; 7(4):320-8. 
124. Brownlee JW, Turner RB. New developments in the epidemiology and clinical spectrum of rhinovirus infections. Curr Opin Pediatr. 2008;20(1):67-71

125. Cassat JE, Skaar EP. Iron in infection and immunity. Cell Host Microbe. 2013; 13(5):509-19.

126. De Voss JJ, Rutter K, Schroeder BG, Barry CE. Iron acquisition and metabolism by mycobacteria. J Bacteriol. 1999;181(15):4443-51.

127. Zoued A, Brunet YR, Durand E, Aschtgen MS, Logger L, Douzi B, Journet L, Cambillau C, Cascales E. Architecture and assembly of the type VI secretion system. Biochim Biophys Acta. 2014;1843(8):1664-73.

128. Eichner A, Gunther N, Arnold M, Schobert M, Heesemann J, Hogardt M. Marker genes for the metabolic adaptation of Pseudomonas aeruginosa to the hypoxic cystic fibrosis lung environment. Int J Med Microbiol. 2014;304(8):1050-61.

129. Hood RD, Singh P, Hsu F, Guvener T, Carl MA, Trinidad RR, Silverman JM Ohlson BB, Hicks KG, Plemel RL, et al. A type VI secretion system of Pseudomonas aeruginosa targets a toxin to bacteria. Cell Host Microbe. 2010;7(1):25-37.

130. Benz J, Sendlmeier C, Barends TR, Meinhart A. Structural insights into the effector-immunity system Tse1/Tsi1 from Pseudomonas aeruginosa. PLoS One. 2012;7(7):e40453.

131. Russell AB, Hood RD, Bui NK, Leroux M, Vollmer W, Mougous JD. Type VI secretion delivers bacteriolytic effectors to target cells. Nature. 2011; 475(7356):343-7

132. Sibley CD, Surette $M G$. The polymicrobial nature of airway infections in cystic fibrosis: cangene gold medal lecture. Can J Microbiol. 2011;57(2):69-77.

133. Delhaes L, Monchy S, Frealle E, Hubans C, Salleron J, Leroy S, Prevotat A Wallet F, Wallaert B, Dei-Cas E, et al. The airway microbiota in cystic fibrosis: a complex fungal and bacterial community-implications for therapeutic management. PLoS One. 2012;7(4):e36313.

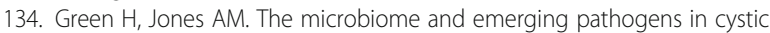
fibrosis and non-cystic fibrosis bronchiectasis. Semin Respir Crit Care Med. 2015;36(2):225-35.

135. Keravec M, Mounier J, Prestat E, Vallet S, Jansson JK, Burgaud G, Rosec S, Gouriou S, Rault G, Coton E, et al. Insights into the respiratory tract microbiota of patients with cystic fibrosis during early Pseudomonas aeruginosa colonization. Springerplus. 2015;4(1):405.

136. Willger SD, Grim SL, Dolben EL, Shipunova A, Hampton TH, Morrison HG, Filkins LM, O'toole GA, Moulton LA, Ashare A, et al. Characterization and quantification of the fungal microbiome in serial samples from individuals with cystic fibrosis. Microbiome. 2014;2:40.

137. Venkataraman A, Bassis CM, Beck JM, Young VB, Curtis JL, Huffnagle GB, Schmidt TM. Application of a neutral community model to assess structuring of the human lung microbiome. MBio. 2015;6(1):e02284-02214.

138. Bassis CM, Erb-Downward JR, Dickson RP, Freeman CM, Schmidt TM, Young VB, Beck JM, Curtis JL, Huffnagle GB. Analysis of the upper respiratory tract microbiotas as the source of the lung and gastric microbiotas in healthy individuals. MBio. 2015;6(2):e00037-00015.

139. Moran LP, Chouvarine P, Dorda M, Hedtfeld S, Mielke S, Schulz A, Wiehlmann L, Tummler B. The cystic fibrosis lower airways microbial metagenome. ERJ Open Res. 2016;2:2.

140. Hoen AG, Li J, Moulton LA, O'toole GA, Housman ML, Koestler DC, Guill MF, Moore $\mathrm{JH}$, Hibberd PL, Morrison HG, et al. Associations between gut microbial colonization in early life and respiratory outcomes in cystic fibrosis. J Pediatr. 2015;167(1):138-47.

141. Renwick J, Mcnally P, John B, Desantis T, Linnane B, Murphy P, On Behalf Of Shield Cf. The microbial community of the cystic fibrosis airway is disrupted in early life. PLoS One. 2014;9(12):e109798.

142. Coutinho HD, Falcão-Silva VS, Gonçalves GF. Pulmonary bacterial pathogens in cystic fibrosis patients and antibiotic therapy: a tool for the health workers. Int Arch Med. 2008;1:24.

143. Cystic Fibrosis Patient Registry 2014 Annual Data Report, Bethesda, Maryland, USA. (2015)https://www.cff.org/2014_CFF_Annual_Data_Report_ to_the_Center_Directors.pdf/. Accessed 29 June 2016.

144. Coburn B, Wang PW, Diaz Caballero J, Clark ST, Brahma V, Donaldson S, Zhang Y, Surendra A, Gong Y, Elizabeth Tullis D, et al. Lung microbiota across age and disease stage in cystic fibrosis. Sci Rep. 2015;5(5):10241.

145. Middleton PG, Chen SC, Meyer W. Fungal infections and treatment in cystic fibrosis. Curr Opin Pulm Med. 2013;19(6):670-5.

146. Parize P, Billaud S, Bienvenu AL, Bourdy S, Le Pogam MA, Reix P, Picot S, Robert R, Lortholary O, Bouchara JP, et al. Impact of Scedosporium apiospermum complex seroprevalence in patients with cystic fibrosis. J Cyst Fibros. 2014;13(6):667-73
147. Pihet M, Carrere J, Cimon B, Chabasse D, Delhaes L, Symoens F, Bouchara JP. Occurrence and relevance of filamentous fungi in respiratory secretions of patients with cystic fibrosis-a review. Med Mycol. 2009;47(4):387-97.

148. Mouhajir A, Matray O, Giraud S, Mély L, Marguet C, Sermet-Gaudelus I, Le Gal S, Labbé F, Person C, Troussier F, et al. Long-term Rasamsonia argillacea complex species colonization revealed by PCR amplification of repetitive DNA sequences in cystic fibrosis patients. J Clin Microbiol. 2016;54(11):2804-12.

149. Lim YW, Schmieder R, Haynes M, Willner D, Furlan M, Youle M, Abbott K, Edwards R, Evangelista J, Conrad D, et al. Metagenomics and metatranscriptomics: windows on CF-associated viral and microbial communities. J Cyst Fibros. 2013;12(2):154-64

150. Willner D, Furlan M, Haynes M, Schmieder R, Angly FE, Silva J, Tammadoni S, Nosrat B, Conrad D, Rohwer F. Metagenomic analysis of respiratory tract DNA viral communities in cystic fibrosis and non-cystic fibrosis individuals. PLoS One. 2009;4(10):e7370.

151. Ouennane S, Leprohon P, Moineau S. Diverse virulent pneumophages infect Streptococcus mitis. PLoS One. 2015;10(2):e0118807.

152. Carmody LA, Zhao J, Kalikin LM, Lebar W, Simon RH, Venkataraman A, Schmidt TM, Abdo Z, Schloss PD, Lipuma JJ. The daily dynamics of cystic fibrosis airway microbiota during clinical stability and at exacerbation. Microbiome. 2015:3:12

153. Hector A, Frey N, Hartl D. Update on host-pathogen interactions in cystic fibrosis lung disease. Mol Cell Pediatr. 2016;3(1):12.

154. Rogers GB, Van Der Gast CJ, Cuthbertson L, Thomson SK, Bruce KD, Martin ML, Serisier DJ. Clinical measures of disease in adult non-CF bronchiectasis correlate with airway microbiota composition. Thorax. 2013;68(8):731-7.

155. Stressmann FA, Rogers GB, Van Der Gast CJ, Marsh P, Vermeer LS, Carroll MP, Hoffman L, Daniels TW, Patel N, Forbes B, et al. Long-term cultivationindependent microbial diversity analysis demonstrates that bacterial communities infecting the adult cystic fibrosis lung show stability and resilience. Thorax. 2012;67(10):867-73.

156. Cox MJ, Allgaier M, Taylor B, Baek MS, Huang YJ, Daly RA, Karaoz U, Andersen GL, Brown R, Fujimura KE, et al. Airway microbiota and pathogen abundance in age-stratified cystic fibrosis patients. PLoS One. 2010;5:e11044

157. Flanagan JL, Brodie EL, Weng L, Lynch SV, Garcia O, Brown R, Hugenholtz P, Desantis TZ, Andersen GL, Wiener-Kronish JP, et al. Loss of bacterial diversity during antibiotic treatment of intubated patients colonized with Pseudomonas aeruginosa. J Clin Microbiol. 2007;45(6):1954-62.

158. Hartl D, Gaggar A, Bruscia E, Hector A, Marcos V, Jung A, Greene C, Mcelvaney G, Mall M, Doring G. Innate immunity in cystic fibrosis lung disease. J Cyst Fibros. 2012;11(5):363-82.

159. Pohl K, Hayes E, Keenan J, Henry M, Meleady P, Molloy K, Jundi B, Bergin DA, Mccarthy C, Mcelvaney OJ, et al. A neutrophil intrinsic impairment affecting Rab27a and degranulation in cystic fibrosis is corrected by CFTR potentiator therapy. Blood. 2014;124(7):999-1009.

160. Gao L, Kim KJ, Yankaskas JR, Forman HJ. Abnormal glutathione transport in cystic fibrosis airway epithelia. Am J Physiol. 1999;277(1 Pt 1):L113-8.

161. Xu Y, Szep S, Lu Z. The antioxidant role of thiocyanate in the pathogenesis of cystic fibrosis and other inflammation-related diseases. Proc Natl Acad Sci U S A. 2009;106(48):20515-9.

162. Branzk N, Lubojemska A, Hardison SE, Wang Q, Gutierrez MG, Brown GD, Papayannopoulos V. Neutrophils sense microbe size and selectively release neutrophil extracellular traps in response to large pathogens. Nat Immunol. 2014;15(11):1017-25

163. Dubois AV, Gauthier A, Bréa D, Varaigne F, Diot P, Gauthier F, Attucci S. Influence of DNA on the activities and inhibition of neutrophil serine proteases in cystic fibrosis sputum. Am J Respir Cell Mol Biol. 2012;47(1):80-6.

164. Gifford AM, Chalmers JD. The role of neutrophils in cystic fibrosis. Curr Opin Hematol. 2014;21(1):16-22.

165. Wagner CJ, Schultz C, Mall MA. Neutrophil elastase and matrix metalloproteinase 12 in cystic fibrosis lung disease. Mol Cell Pediatr. 2016; 3(1):25.

166. Yoo DG, Winn M, Pang L, Moskowitz SM, Malech HL, Leto TL, Rada B. Release of cystic fibrosis airway inflammatory markers from Pseudomonas aeruginosa-stimulated human neutrophils involves NADPH oxidasedependent extracellular DNA trap formation. J Immunol. 2014;192(10):4728-38.

167. Descamps D, Le Gars M, Balloy V, Barbier D, Maschalidi S, Tohme M, Chignard M, Ramphal R, Manoury B, Sallenave JM. Toll-like receptor 5 (TLR5), IL-1 $\beta$ secretion, and asparagine endopeptidase are critical factors for alveolar macrophage phagocytosis and bacterial killing. Proc Natl Acad Sci. 2012;109(5):1619-24. 
168. Rieber N, Hector A, Carevic M, Hartl D. Current concepts of immune dysregulation in cystic fibrosis. Int J Biochem Cell Biol. 2014;52:108-12.

169. Anil N, Singh M. CD4+ CD25 high FOXP3+ regulatory T cells correlate with FEV1 in north Indian children with cystic fibrosis. Immunol Invest. 2014;43(6):535-43.

170. Ellis TN, Leiman SA, Kuehn MJ. Naturally produced outer membrane vesicles from Pseudomonas aeruginosa elicit a potent innate immune response via combined sensing of both lipopolysaccharide and protein components. Infect Immun. 2010;78(9):3822-31.

171. Hauser AR. The type III. secretion system of Pseudomonas aeruginosa: infection by injection. Nat Rev Microbiol. 2009;7(9):654-65.

172. Miao EA, Mao DP, Yudkovsky N, Bonneau R, Lorang CG, Warren SE, Leaf IA, Aderem A. Innate immune detection of the type III secretion apparatus through the NLRC4 inflammasome. Proc Natl Acad Sci. 2010;107(7):3076-80.

173. Davis BK, Wen H, Ting JP. The inflammasome NLRs in immunity, inflammation, and associated diseases. Annu Rev Immunol. 2011;29:707-35.

174. Von Moltke J, Ayres JS, Kofoed EM, Chavarria-Smith J, Vance RE. Recognition of bacteria by inflammasomes. Annu Rev Immunol. 2013;31:73-106.

175. Bomberger JM, Ely KH, Bangia N, Ye S, Green KA, Green WR, Enelow RI, Stanton BA. Pseudomonas aeruginosa Cif protein enhances the ubiquitination and proteasomal degradation of the transporter associated with antigen processing (TAP) and reduces major histocompatibility complex (MHC) class I antigen presentation. J Biol Chem. 2014;289(1):152-62.

176. Siegmann N, Worbs D, Effinger F, Bormann T, Gebhardt M, Ulrich M, Wermeling F, Müller-Hermelink E, Biedermann T, Tighe M. Invariant natural killer T (iNKT) cells prevent autoimmunity, but induce pulmonary inflammation in cystic fibrosis. Cell Physiol Biochem. 2014;34(1):56-70.

177. Hofer TP, Frankenberger M, Heimbeck I, Burggraf D, Wjst M, Wright AK, Kerscher M, Nahrig S, Huber RM, Fischer R, et al. Decreased expression of HLA-DQ and HLA-DR on cells of the monocytic lineage in cystic fibrosis. J Mol Med (Berl). 2014;92(12):1293-304.

178. Shijubo N, Itoh Y, Yamaguchi T, Imada A, Hirasawa M, Yamada T, Kawai T, Abe S. Clara cell protein-positive epithelial cells are reduced in small airways of asthmatics. Am J Respir Crit Care Med. 1999;160(3):930-3.

179. Laguna TA, Williams CB, Brandy KR, Welchlin-Bradford C, Moen CE, Reilly CS, Wendt $\mathrm{CH}$. Sputum club cell protein concentration is associated with pulmonary exacerbation in cystic fibrosis. J Cyst Fibros. 2015;14(3):334-40.

180. Cohen TS, Prince A. Cystic fibrosis: a mucosal immunodeficiency syndrome. Nat Med. 2012;18(4):509-19.

181. Collaco JM, Blackman SM, Mcgready J, Naughton KM, Cutting GR. Quantification of the relative contribution of environmental and genetic factors to variation in cystic fibrosis lung function. J Pediatr. 2010;157(5):802-7.

182. Schechter MS. Non-genetic influences on cystic fibrosis lung disease: the role of sociodemographic characteristics, environmental exposures, and healthcare interventions. Semin Respir Crit Care Med. 2003;24(6):639-52.

183. Schechter MS. Wealth as a disease modifier in cystic fibrosis. Lancet Respir Med. 2013;1(2):93-5.

184. Schoni MH, Casaulta-Aebischer C. Nutrition and lung function in cystic fibrosis patients: review. Clin Nutr. 2000;19(2):79-85.

185. Dror T, Dickstein Y, Dubourg G, Paul M. Microbiota manipulation for weight change. Microb Pathog. 2016. http://dx.doi.org/10.1016/j.micpath.2016.01. 002. Epub ahead of print.

186. Psoter KJ, De Roos AJ, Mayer JD, Kaufman JD, Wakefield J, Rosenfeld M. Fine particulate matter exposure and initial Pseudomonas aeruginosa acquisition in cystic fibrosis. Ann Am Thorac Soc. 2015;12(3):385-91.

187. Jassal MS, Yu AM, Bhatia R, Keens TG, Davidson Ward SL. Effect of residential proximity to major roadways on cystic fibrosis exacerbations. Int J Environ Health Res. 2013;23(2):119-31.

188. Welsh MJ. Cigarette smoke inhibition of ion transport in canine tracheal epithelium. J Clin Invest. 1983;71(6):1614-23.

189. Kopp B, Ortega-García J, Sadreameli S, Wellmerling J, Cormet-Boyaka E, Thompson R, Mcgrath-Morrow S, Groner J. The impact of secondhand smoke exposure on children with cystic fibrosis: a review. Int J Environ Res Public Health. 2016;13(10):1003

190. Kopp BT, Sarzynski L, Khalfoun S, Hayes Jr D, Thompson R, Nicholson L, Long F, Castile R, Groner J. Detrimental effects of secondhand smoke exposure on infants with cystic fibrosis. Pediatr Pulmonol. 2015;50(1):25-34.

191. Rand S, Prasad SA. Exercise as part of a cystic fibrosis therapeutic routine. Expert Rev Respir Med. 2012;6(3):341-52.

192. Collaco JM, Blackman SM, Raraigh KS, Morrow CB, Cutting GR, Paranjape SM. Self-reported exercise and longitudinal outcomes in cystic fibrosis: a retrospective cohort study. BMC Pulm Med. 2014;14(1):159.
193. Grossoehme DH, Szczesniak RD, Mrug S, Dimitriou SM, Marshall A, Mcphail GL. Adolescents' spirituality and cystic fibrosis airway clearance treatment adherence: examining mediators. J Pediatr Psychol. 2016;41(9):1022-32.

194. Platten MJ, Newman E, Quayle E. Self-esteem and its relationship to mental health and quality of life in adults with cystic fibrosis. J Clin Psychol Med Settings. 2012;20(3):392-9.

195. Besier S, Smaczny C, Mallinckrodt C, Krahl A, Ackermann H, Brade V. Prevalence and clinical significance of Staphylococcus aureus small-colony variants in cystic fibrosis lung disease. J Clin Microbiol. 2007;45(1):168-72.

196. Bodnar R, Kadar L, Szabo L, Hernadi M, Mikoczi M, Meszaros A. Health related quality of life of children with chronic respiratory conditions. Adv Clin Exp Med. 2015;24(3):487-95.

197. Sutton MT, Fletcher D, Ghosh SK, Weinberg A, Van Heeckeren R, Kaur S, Sadeghi Z, Hijaz A, Reese J, Lazarus HM, et al. Antimicrobial properties of mesenchymal stem cells: therapeutic potential for cystic fibrosis infection, and treatment. Stem Cells Int. 2016;2016:1-12.

198. Martiniano SL, Sagel SD, Zemanick ET. Cystic fibrosis. Curr Opin Pediatr. 2016;28(3):312-7.

199. Sinagoga KL, Wells JM. Generating human intestinal tissues from pluripotent stem cells to study development and disease. EMBO J. 2015;34(9):1149-63.

200. Mcneer NA, Anandalingam K, Fields RJ, Caputo C, Kopic S, Gupta A, Quijano E, Polikoff L, Kong Y, Bahal R, et al. Nanoparticles that deliver triplex-forming peptide nucleic acid molecules correct F508del CFTR in airway epithelium. Nat Commun. 2015;6:6952

201. Maeder ML, Gersbach CA. Genome-editing technologies for gene and cell therapy. Mol Ther. 2016;24(3):430-46.

202. Paul-Smith MC, Bell RV, Alton WE, Alton EWFW, Griesenbach U. Gene therapy for cystic fibrosis: recent progress and current aims. Expert Opin Orphan Drugs. 2016;4(6):649-58.

203. Mueller C, Flotte TR. Gene therapy for cystic fibrosis. Clin Rev Allergy Immunol. 2008;35(3):164-78.

204. Harrison MJ, Murphy DM, Plant BJ. Ivacaftor in a G551D homozygote with cystic fibrosis. N Engl J Med. 2013;369(13):1280-2.

205. Beringer PM, Bensman TJ, Ho H, Agnello M, Denovel N, Nguyen A, WongBeringer A, She R, Tran Dat Q, Moskowitz SM, et al. Rhesus $\theta$-defensin-1 (RTD-1) exhibits in vitro and in vivo activity against cystic fibrosis strains of Pseudomonas aeruginosa. J Antimicrob Chemother. 2015;71(1):181-8.

206. Mcmillan J, Batrakova E, Gendelman HE. Cell delivery of therapeutic nanoparticles. Prog Mol Biol Transl Sci. 2011;104:563-601.

207. Friman VP, Soanes-Brown D, Sierocinski P, Molin S, Johansen HK, Merabishvili M, Pirnay JP, De Vos D, Buckling A. Pre-adapting parasitic phages to a pathogen leads to increased pathogen clearance and lowered resistance evolution with Pseudomonas aeruginosa cystic fibrosis bacterial isolates. J Evol Biol. 2015;29(1):188-98.

208. Wainwright CE, Elborn JS, Ramsey BW, Marigowda G, Huang X, Cipolli M, Colombo C, Davies JC, De Boeck K, Flume PA, et al. Lumacaftor-Ivacaftor in patients with cystic fibrosis homozygous for phe508del CFTR. N Engl J Med. 2015;373(3):220-31.

209. Waters V, Yau Y, Prasad S, Lu A, Atenafu E, Crandall I, Tom S, Tullis E, Ratjen F. Stenotrophomonas maltophilia in cystic fibrosis: serologic response and effect on lung disease. Am J Respir Crit Care Med. 2011;183(5):635-40.

210. Dasenbrook EC, Merlo CA, Diener-West M, Lechtzin N, Boyle MP. Persistent methicillin-resistant Staphylococcus aureus and rate of FEV1 decline in cystic fibrosis. Am J Respir Crit Care Med. 2008;178(8):814-21.

211. Chmiel JF, Aksamit TR, Chotirmall SH, Dasenbrook EC, Elborn JS, Lipuma JJ, Ranganathan SC, Waters VJ, Ratjen FA. Antibiotic management of lung infections in cystic fibrosis. I. The microbiome, methicillin-resistant staphylococcus aureus, gram-negative bacteria, and multiple infections. Ann Am Thorac Soc. 2014;11(7):1120-9.

212. Malouf MA, Glanville AR. The spectrum of mycobacterial infection after lung transplantation. Am J Respir Crit Care Med. 1999;160(5):1611-6.

213. Binder AM, Adjemian J, Olivier KN, Prevots DR. Epidemiology of nontuberculous mycobacterial infections and associated chronic macrolide use among persons with cystic fibrosis. Am J Respir Crit Care Med. 2013; 188(7):807-912.

214. Mahenthiralingam E. Emerging cystic fibrosis pathogens and the microbiome. Paediatr Respir Rev. 2014;15 Suppl 1:13-15.

215. Zemanick ET, Sagel SD, Harris JK. The airway microbiome in cystic fibrosis and implications for treatment. Curr Opin Pediatr. 2011;23(3):319-24.

216. Tunney MM, Field TR, Moriarty TF, Patrick S, Doering G, Muhlebach MS, Wolfgang MC, Boucher R, Gilpin DF, Mcdowell A, et al. Detection of 
anaerobic bacteria in high numbers in sputum from patients with cystic fibrosis. Am J Respir Crit Care Med. 2008;177(9):995-1001.

217. Sibley CD, Grinwis ME, Field TR, Parkins MD, Norgaard JC, Gregson DB, Rabin HR, Surette MG. McKay agar enables routine quantification of the 'Streptococcus milleri'group in cystic fibrosis patients. J Med Microbiol. 2010; 59(5):534-40.

218. Rabin HR, Surette MG. The cystic fibrosis airway microbiome. Curr Opin Pulm Med. 2012;18(6):622-7.

219. Stevens DA, Moss RB, Hernandez C, Clemons KV, Martinez M. Effect of media modified to mimic cystic fibrosis sputum on the susceptibility of Aspergillus fumigatus, and the frequency of resistance at one center. Antimicrob Agents Chemother. 2016;60(4):2180-4.

220. Speirs JJ, Van Der Ent CK, Beekman JM. Effects of Aspergillus fumigatus colonization on lung function in cystic fibrosis. Curr Opin Pulm Med. 2012; 18(6):632-8.

221. Heirali A, Mckeon S, Purighalla S, Storey DG, Rossi L, Costilhes G, Drews SJ, Rabin HR, Surette MG, Parkins MD. Assessment of the microbial constituents of the home environment of individuals with cystic fibrosis (CF) and their association with lower airways infections. PLoS One. 2016;11(2):e0148534.

222. Caverly L, Carmody LA, Haig SJ, Kotlarz N, Kalikin LM, Raskin L, Lipuma JJ. Culture-independent identification of nontuberculous mycobacteria in cystic fibrosis respiratory samples. PLoS One. 2016;11(4):e0153876.

223. Horré $R$, Symoens $F$, Delhaes $L$, Bouchara JP. Fungal respiratory infections in cystic fibrosis: a growing problem. Med Mycol. 2010;48(Supplement 1):S1-3.

224. Mogayzel PJ, Naureckas ET, Robinson KA, Mueller G, Hadjiliadis D, Hoag JB, Lubsch L, Hazle L, Sabadosa K, Marshall B. Cystic fibrosis pulmonary guidelines. Am J Respir Crit Care Med. 2013;187(7):680-9.

225. Donaldson SH, Bennett WD, Zeman KL, Knowles MR, Tarran R, Boucher RC. Mucus clearance and lung function in cystic fibrosis with hypertonic saline. N Engl J Med. 2006;354(3):241-50.

226. Assael BM, Pressler T, Bilton D, Fayon M, Fischer R, Chiron R, Larosa M, Knoop C, Mcelvaney N, Lewis SA, et al. Inhaled aztreonam lysine vs. inhaled tobramycin in cystic fibrosis: a comparative efficacy trial. J Cyst Fibros. 2013; 12(2):130-40.

227. Schuster A, Haliburn C, Doring G, Goldman MH. Safety, efficacy and convenience of colistimethate sodium dry powder for inhalation (Colobreathe DPI) in patients with cystic fibrosis: a randomised study. Thorax. 2012;68(4):344-50.

228. Uzun S, Djamin RS, Kluytmans JA, Mulder PG, Van't Veer NE, Ermens AA, Pelle AJ, Hoogsteden HC, Aerts JG, Van Der Eerden MM. Azithromycin maintenance treatment in patients with frequent exacerbations of chronic obstructive pulmonary disease (COLUMBUS): a randomised, double-blind, placebo-controlled trial. Lancet Respir Med. 2014;2(5):361-8.

229. Saiman L, Anstead M, Mayer-Hamblett N, Lands LC, Kloster M, HocevarTrnka J, Goss CH, Rose LM, Burns JL, Marshall BC, et al. Effect of azithromycin on pulmonary function in patients with cystic fibrosis uninfected with Pseudomonas aeruginosa: a randomized controlled trial. JAMA. 2010;303(17):1707-15.

230. Lands LC, Milner R, Cantin AM, Manson D, Corey M. High-dose ibuprofen in cystic fibrosis: canadian safety and effectiveness trial. J Pediatr. 2007;151(3): 249-54.

231. De Boeck K, Munck A, Walker S, Faro A, Hiatt P, Gilmartin G, Higgins M. Efficacy and safety of ivacaftor in patients with cystic fibrosis and a nonG551D gating mutation. J Cyst Fibros. 2014;13(6):674-80.

232. Dekkers JF, Wiegerinck CL, De Jonge HR, De Jong NWM, Bijvelds MJC, Nieuwenhuis EES, Van Den Brink S, Clevers H, Van Der Ent CK, Middendorp S. A functional CFTR assay using primary cystic fibrosis intestinal organoids. J Cyst Fibros. 2012;11:S32.

233. Van Goor F, Hadida S, Grootenhuis PD, Burton B, Cao D, Neuberger T, Turnbull A, Singh A, Joubran J, Hazlewood A, et al. Rescue of CF airway epithelial cell function in vitro by a CFTR potentiator, VX-770. Proc Natl Acad Sci. 2009;106(44):18825-30.

234. Du M, Liu X, Welch EM, Hirawat S, Peltz SW, Bedwell DM. PTC124 is an orally bioavailable compound that promotes suppression of the human CFTRG542X nonsense allele in a CF mouse model. Proc Natl Acad Sci. 2008; 105(6):2064-9.

\section{Submit your next manuscript to BioMed Central and we will help you at every step:}

- We accept pre-submission inquiries

- Our selector tool helps you to find the most relevant journal

- We provide round the clock customer support

- Convenient online submission

- Thorough peer review

- Inclusion in PubMed and all major indexing services

- Maximum visibility for your research

Submit your manuscript at www.biomedcentral.com/submit

) Biomed Central 